Revista Eletrônica de Direito Processual - REDP. Volume 16. Julho a dezembro de 2015

Periódico Semestral da Pós-Graduação Stricto Sensu em Direito Processual da UERJ

Patrono: José Carlos Barbosa Moreira. ISSN 1982-7636. pp. 449-477 http://www.e-publicacoes.uerj.br/index.php/redp/index

\title{
O JUIZ LEIGO NOS JUIZADOS ESPECIAIS CÍVEIS E NOS JUIZADOS \\ ESPECIAIS DA FAZENDA PÚBLICA: EFICIÊNCIA VERSUS ACESSO AO \\ JUDICIÁRIO E AO DIREITO'
}

\author{
THE LAY JUDGE IN THE SMALL CLAIMS COURTS AND IN THE SMALL \\ CLAIMS AGAINST THE EXCHEQUER COURTS: EFFICIENCY VERSUS ACCESS \\ TO JUSTICE AND TO LAW
}

Pedro Gomes de Queiroz

Doutorando e Mestre em Direito Processual pela UERJ.

Prof. substituto de Prática Jurídica Cível da UFRJ

Especialista em Direito Processual Civil pela PUC-Rio

Advogado

advocacia115@gmail.com

RESUMO: Os juízes leigos que atuam perante os Juizados Especiais Cíveis e perante os Juizados Especiais da Fazenda Pública não têm a legitimidade necessária para tomar decisões discricionárias ou baseadas em pura equidade, pois não são eleitos diretamente pelo povo. Assim, devem basear suas decisões no ordenamento jurídico vigente. Para tanto, o processo de seleção destes deve exigir o conhecimento jurídico e a titulação necessários para o exercício da função. O juiz leigo submete-se aos motivos de impedimento e de suspeição do juiz togado, pois é um auxiliar da justiça. Por esta razão, a lei deve reconhecer o direito do jurisdicionado de conhecer a pessoa física que exerce a função em seu processo.

PALAVRAS-CHAVE: juiz leigo, seleção, legitimidade, conciliação, projeto de sentença, sentença homologatória, minuta de decisão judicial, arbitragem, execução, princípio da cooperação, remuneração.

\footnotetext{
${ }^{1}$ Artigo recebido em 28/12/2014 e aprovado em 10/06/2015.
} 
Revista Eletrônica de Direito Processual - REDP. Volume 16. Julho a dezembro de 2015

Periódico Semestral da Pós-Graduação Stricto Sensu em Direito Processual da UERJ

Patrono: José Carlos Barbosa Moreira. ISSN 1982-7636. pp. 449-477 http://www.e-publicacoes.uerj.br/index.php/redp/index

ABSTRACT: Lay judges that work at small claims courts and at small claims against the Exchequer courts don't have the necessary legitimacy to take discretionary or solely based in equity decisions, because they are not directly elected by the people. Thus, they must base their decisions in the present Law. For this purpose, the selection process of them must demand the necessary legal knowledge and degree for the exercise of the function. The lay judge is submitted to the reasons of impediment or suspicion of the judge, because he is an assistant of the Justice, so the law must recognize the citizen's right to know the individual that exercises the function in his process.

KEYWORDS: lay judge, selection, legitimacy, conciliation, project of judgment, ratification, draft ruling, arbitration, enforcement, cooperation, payment.

SUMÁRIO: 1. Introdução. 2. Critério de seleção e legitimidade dos juízes leigos. 3. Impedimento ao exercício da advocacia para o juiz leigo. 4. Conciliação conduzida por juiz leigo. 5. A instrução probatória conduzida por juiz leigo. 6. O projeto de sentença do juiz leigo e a sentença do juiz togado que o homologa. 7. A arbitragem nos juizados especiais cíveis e o juiz leigo. 8. Embargos à execução de sentença, embargos à execução de título executivo extrajudicial e juiz leigo. 9. Natureza jurídica do juiz leigo. 10. O Princípio da cooperação e o juiz leigo. 11. A remuneração do juiz leigo. 12. Considerações finais. Referências.

\section{Introdução}

A excessiva demora dos processos judiciais levou, dentre outras coisas, à criação de auxiliares da justiça encarregados de proferir decisões que envolvem tanto o Direito Material quanto o Direito Processual discutidos em processos judiciais. São estes o juiz leigo ${ }^{2}$ que atua nos Juizados Especiais Cíveis ${ }^{3}$ e nos Juizados Especiais da Fazenda Pública ${ }^{4}$. Mas estariam estes profissionais aptos a exercer uma tarefa que, outrora, era exclusiva do juiz togado? Sua disciplina legal e infralegal atende às exigências constitucionais? Seu trabalho

\footnotetext{
${ }^{2}$ Cf. art. 98, I, da Constituição Federal de 1988.

${ }^{3}$ Cf. arts. $7^{\circ}, 21,22,24,37$ e 40 , da Lei 9.099/1995.

${ }^{4}$ Cf. art. 15 da Lei $12.153 / 2009$.
} 
Revista Eletrônica de Direito Processual - REDP. Volume 16. Julho a dezembro de 2015

Periódico Semestral da Pós-Graduação Stricto Sensu em Direito Processual da UERJ

Patrono: José Carlos Barbosa Moreira. ISSN 1982-7636. pp. 449-477 http://www.e-publicacoes.uerj.br/index.php/redp/index

realmente amplia o acesso da população ao Judiciário e ao Direito? A seguir procuraremos analisar as normas, a doutrina e a jurisprudência acerca do juiz leigo, abordando aspectos como seu processo de seleção, sua legitimidade, suas atribuições e seu modo de remuneração.

\section{Critério de seleção e legitimidade dos juízes leigos}

A função do Judiciário é concebida de diferentes formas no sistema continental europeu - civil law - e no sistema adotado pelo Reino Unido e pelos países que foram colonizados por este, denominado common law. Enquanto na civil law a principal missão da justiça tem sido a atuação do direito objetivo, isto é, a aplicação da vontade concreta da lei aos casos que lhe são submetidos, sendo a paz social um fim secundário, na common law a função preponderante da justiça é pacificar os litigantes, de modo a preservar a coesão e a solidariedade entre os membros da comunidade. Assim, pouco importa se a reconciliação entre as partes será alcançada por meio da aplicação da lei ou de outro critério que se revele mais adequado ao caso concreto ${ }^{5}$.

\footnotetext{
${ }^{5}$ Segundo Leonardo Greco, "no sistema continental europeu (civil law), a função do Judiciário, o papel da justiça, tem sido o de atuação do direito objetivo, isto é, a aplicação da vontade concreta da lei aos casos que lhe são submetidos. A jurisdição, que por ora caracterizamos apenas como a função dos juízes, é vista como instrumento da lei, mesmo por aqueles autores que procuram dar ênfase aos reflexos que essa atividade produz na esfera subjetiva dos cidadãos e dos particulares que a ela recorrem.

$\mathrm{Na}$ civil law, que é o nosso sistema jurídico, a jurisdição tem sido estruturada preponderantemente com a finalidade de atuação do direito objetivo e por isso a administração da justiça adota o que Damaska denominou de modelo hierárquico, centralizador. Nesse sistema, os juízes são considerados a boca da lei, expressão usada por Montesquieu para justificar a ideia de que os poderes dos juízes decorrem da lei e à lei devem estar sempre subordinados. É imperioso que os juízes inferiores estejam rigidamente controlados pelos tribunais superiores para que se mantenham fiéis a essa missão de serem o instrumento de cumprimento da lei. Já no modelo de administração da justiça dos países da common law, a função da justiça é, de modo preponderante, a de pacificação dos litigantes. A paz social na civil law é um objetivo remoto. Já na common law, a paz entre os litigantes, a rearmonização, a reconciliação é o seu objetivo direto, imediato. Na common law, pouco importa se a pacificação dos litigantes vai dar-se à luz da lei ou de outro critério qualquer que seja mais adequado ao caso concreto. O importante é harmonizar os litigantes. Isso porque a justiça da common law tem um profundo enraizamento na vida da comunidade e tem por função primordial preservar a coesão e a solidariedade entre os seus membros, interdependentes entre si.

Enquanto a justiça da civil law tem sido a justiça do rei, do soberano, do Estado, a justiça da common law é a justiça paritária, da comunidade. GRECO, Leonardo. Instituições de Processo Civil. 3. ed. Rio de janeiro: Forense, 2011. 2 v. V. 1: Introdução ao Direito Processual Civil, p. 2.
} 
Revista Eletrônica de Direito Processual - REDP. Volume 16. Julho a dezembro de 2015

Periódico Semestral da Pós-Graduação Stricto Sensu em Direito Processual da UERJ

Patrono: José Carlos Barbosa Moreira. ISSN 1982-7636. pp. 449-477 http://www.e-publicacoes.uerj.br/index.php/redp/index

O legislador brasileiro inspirou-se nas small claims courts do direito norte-americano para criar os juizados de pequenas causas ${ }^{6}$ e, mais tarde, os juizados especiais ${ }^{7}$, "em busca de uma justiça mais pacificadora do que sentenciadora". Assim, procurou sanar falhas de nosso Direito, tradicionalmente baseado na civil law, com a importação de institutos da common law, o que se tornou problemático, na prática, tendo em vista as diferenças culturais existentes entre o Brasil e os Estados Unidos da América ${ }^{8}$.

O intercâmbio de institutos jurídicos entre países pertencentes à common law e à civil law, verificado nas últimas décadas, acabou por atenuar as diferenças existentes entre os dois sistemas, sem contudo extingui-las por completo, até porque muitas delas têm origem na cultura, que a mera mudança da lei não é capaz de transformar".

Nos países da common law, os julgadores são, em sua maioria, profissionais do Direito eleitos diretamente pelo povo ou indicados por políticos para a função de juiz ou, ainda, jurados, sem formação jurídica ${ }^{10}$. Por outro lado, na civil law, a maioria dos julgadores

6 Cf. BRASIL. Lei 7.244, de 7 de novembro de 1984 . Disponível em: $<$ http://www.planalto.gov.br/ccivil_03/leis/1980-1988/L7244.htm>. Acesso em: 13 out. 2014.

${ }^{7}$ Cf. art. 98, I, da Constituição Federal e Lei 9099/1995.

${ }^{8}$ Segundo Leonardo Greco: "Deficiências do sistema da civil law vão sendo resolvidas pela importação de mecanismos da common law. [...] Inversamente, em países do sistema da common law, como a Inglaterra, também as suas deficiências têm ido buscar soluções em técnicas adotadas em países da civil law. [...] De qualquer modo, nossa doutrina toda foi concebida à luz do sistema continental europeu, do sistema hierárquico, do processo como instrumento do direito objetivo. As importações que se fazem de institutos da common law sempre entram no nosso sistema de uma forma um pouco extravagante, anômala e o sistema tem dificuldade de assimilar esses novos institutos ou até mesmo acaba por desvirtuar as suas finalidades ou características. GRECO, Leonardo. Op. cit., p. 3-4.

${ }_{9}$ Nesse sentido, Leonardo Greco observa que: "o processo judicial é uma atividade prática, exercida repetitivamente todos os dias por pessoas, como juízes, advogados, promotores, serventuários, que, apesar da sua formação acadêmica, fazem parte de povos com costumes, tradições e experiências políticas e sociais muito diferentes. O processo é um fenômeno cultural, típico de cada povo e, até mesmo, de cada comunidade. As reformas legais não conseguem transformá-lo da noite para o dia. GRECO, Leonardo. Ibid, p. 9. No mesmo sentido, Oscar Chase observa que: "Há uma interação contínua no processo entre a lei e a realidade. Uma influencia a outra e, por isso, a justiça ideal não será obra apenas dos legisladores, mas também e principalmente dos educadores e de todos os que possam contribuir para impregnar na consciência coletiva os valores humanitários sobre os quais a sociedade deve viver". CHASE, Oscar G., Law, Culture and Ritual disputing systems in cross-cultural context, New York University Press, 2005 apud GRECO, Leonardo. Op. cit., p. 9.

${ }^{10}$ Roberto Kant de Lima observa que: "Nos Estados Unidos o sistema de júri é considerado, segundo a ideologia legal, como um conjunto uniforme de procedimentos, que constitui o "due process of law". Ao sistema de júri é atribuída uma função política. Considera-se o júri responsável pela doutrinação da população sobre valores democráticos e legais. Diz-se que o júri funciona como uma "escola pública" [...], cujo sistema de justiça demonstra ao cidadão comum a excelência de seu sistema político e legal. Considera-se que os veredictos do júri legitimam as decisões emanadas do "povo". A maneira pela qual os direitos de cidadania expandiram-se sobre toda a população dos Estados Unidos, reflete-se na composição do tribunal do júri. Historicamente, a ampliação do direito/obrigação de servir como jurado alcançou primeiro os católicos, depois as mulheres e finalmente os negros. A ideologia jurídica dos Estados Unidos incorpora progressivamente minorias, como sujeitos políticos com direito às garantias universais da cidadania [...]”. LIMA, Roberto Kant 
Revista Eletrônica de Direito Processual - REDP. Volume 16. Julho a dezembro de 2015

Periódico Semestral da Pós-Graduação Stricto Sensu em Direito Processual da UERJ

Patrono: José Carlos Barbosa Moreira. ISSN 1982-7636. pp. 449-477

http://www.e-publicacoes.uerj.br/index.php/redp/index

é selecionada por concurso público de provas e títulos para o cargo de juiz, exercendo a

função jurisdicional de forma remunerada e permanente, gozando de vitaliciedade após certo período de atividade ${ }^{11}$.

Por não ter sido eleito pelo povo, o juiz da civil law não tem legitimidade para adotar decisões discricionárias ou puramente equitativas, devendo sempre baseá-las em normas jurídicas democraticamente elaboradas a exemplo da Constituição e da lei. Os juízos de pura equidade somente são permitidos em casos especificamente previstos na Constituição ou na $1 \mathrm{ei}^{12}$.

$\mathrm{O}$ art. $6^{\circ}$ da Lei 9.099/1995, referente aos Juizados Especiais Cíveis, estabelece que “o Juiz adotará em cada caso a decisão que reputar mais justa e equânime, atendendo aos fins sociais da lei e às exigências do bem comum" ${ }^{13}$. No mesmo sentido, o art. 723, parágrafo único, do CPC/2015, referente à jurisdição voluntária, estabelece que: “o juiz não é obrigado a observar critério de legalidade estrita, podendo adotar em cada caso a solução que

de. A polícia da cidade do Rio de Janeiro: seus dilemas e paradoxos. 1. ed. Rio de Janeiro: Polícia Militar do Estado do Rio de Janeiro, 1994, p. 148.

11 Segundo Leonardo Greco, "Nos países da civil law a jurisdição normalmente é exercida por juízes profissionais, escolhidos por critérios técnicos e que se tornam vitalícios para exercer a judicatura como atividade remunerada de caráter permanente. Diferentemente da civil law, na common law predominam juízes leigos ou juízes profissionais de investidura política”. GRECO, Leonardo. Op. cit., p. 4.

$12 \mathrm{O}$ art. 140, CPC/2015 dispõe que: "Art. 140. O juiz não se exime de decidir sob a alegação de lacuna ou obscuridade do ordenamento jurídico. Parágrafo único. O juiz só decidirá por equidade nos casos previstos em lei”. BRASIL. Código de Processo Civil (Lei 13.105, de 15 de março de 2015). Disponível em: $<$ http://www.planalto.gov.br/ccivil_03/_Ato2015-2018/2015/Lei/L13105.htm>. Acesso em: 09 jun. 2015. O art. $4^{\circ}$, da Lei de Introdução às normas do Direito Brasileiro (Decreto-Lei no 4.657, de 4 de setembro de 1942) estabelece que: "Art. $4^{\circ}$ Quando a lei for omissa, o juiz decidirá o caso de acordo com a analogia, os costumes e os princípios gerais de direito". BRASIL. Lei de Introdução às normas do Direito Brasileiro (Decreto-Lei n ${ }^{\circ}$ 4.657, de 4 de setembro de 1942). Disponível em: <http://www2.camara.leg.br/legin/fed/declei/19401949/decreto-lei-4657-4-setembro-1942-414605-normaatualizada-pe.html>. Acesso em: 09 jun. 2015.

No sentido do texto, Leonardo Greco sustenta que "na civil law, o critério de decisão das causas é rigorosamente um critério de legalidade. Juízos discricionários do juiz são repudiados. As decisões judiciais são, em geral, consideradas atos vinculados, ou seja, atos cujos requisitos estão estabelecidos pela lei. Num espaço muito limitado e rigidamente previsto, a civil law admite atos discricionários ou juízos de equidade, a chamada justiça do caso concreto, como se vê nos artigos 126 e 127 do nosso Código de Processo Civil. O juiz somente decidirá por equidade nos casos previstos em lei. A lei procura limitar juízos discricionários e equitativos". GRECO, Leonardo. Op. cit., p. 4-5. Importa salientar, entretanto, que a equidade não é, tão somente, um elemento de integração do Direito, a ser utilizado quando o caso concreto não puder ser decidido com base na Constituição, na lei, nos princípios gerais do Direito ou nos costumes, tendo em vista a omissão das referidas fontes, já que "mediante juízos de equidade, se amenizam as conclusões esquemáticas da regra genérica, tendo em vista a necessidade de ajustá-la às particularidades que cercam certas hipóteses da vida social. [...] Não raro, pratica injustiça o magistrado que com insensibilidade formalística, segue rigorosamente o mandamento do texto legal. Há casos em que é necessário abrandar o texto, operando-se tal abrandamento através da equidade, que é, portanto, a justiça amoldada à especificidade de uma situação real”. REALE, Miguel. Lições Preliminares de Direito. 27 ed. São Paulo: Saraiva, 2002, p. 298-299.

13 BRASIL. Lei 9.099, de 26 de setembro de 1995. Disponível em: $<$ http://www.planalto.gov.br/ccivil_03/leis/19099.htm>. Acesso em: 15 out. 2014. 
Revista Eletrônica de Direito Processual - REDP. Volume 16. Julho a dezembro de 2015

Periódico Semestral da Pós-Graduação Stricto Sensu em Direito Processual da UERJ

Patrono: José Carlos Barbosa Moreira. ISSN 1982-7636. pp. 449-477 http://www.e-publicacoes.uerj.br/index.php/redp/index

considerar mais conveniente ou oportuna" ${ }^{14}$. Estes artigos, entretanto, não permitem que o juiz decida fora ou contra a lei, apenas the conferem "certa margem de escolha, que deve ser fundamentada, objetiva, a partir de certos critérios". A civil law resiste a juízos discricionários, fundados na conveniência e na oportunidade, bem como àqueles baseados na equidade, que são sempre excepcionais e controlados ${ }^{15}$.

Exemplo de julgamento por equidade é o arbitramento de alimentos, já que o art. 1.694, $\S 1^{\circ}$, do Código Civil estabelece que "os alimentos devem ser fixados na proporção das necessidades do reclamante e dos recursos da pessoa obrigada". Assim, o juiz deve atender às exigências do caso concreto ${ }^{16}$.

Autorizar um juiz profissional, selecionado por concurso público, a decidir fora da lei significa permitir julgamentos arbitrários. Por outro lado, um juiz leigo, escolhido pela comunidade, detém a legitimidade necessária para decidir de acordo com “os ditames da sua consciência e com os sentimentos dessa comunidade”. A Constituição Federal permitiu a ruptura, no Brasil, do paradigma da civil law de uma "justiça profissional, instrumento de revelação do direito objetivo", ao prever, em seu art. 98, I, que os juizados especiais podem ser "providos por juízes togados, ou togados e leigos". Entretanto, nossa cultura não permitiu a superação do referido modelo, já que os juízes leigos que hoje atuam nos juizados especiais brasileiros não são eleitos pelo povo. No Estado do Rio de Janeiro, por exemplo, os juízes leigos são selecionados por concurso público para exercer a função por um período de até dois anos, podendo, entretanto, ser dispensados a qualquer momento, atendendo à conveniência do serviço ${ }^{17}$.

Tendo em consideração que os juízes leigos não são eleitos pelo povo e que, portanto, não detém a legitimidade necessária para proferir decisões baseadas em conveniência e oportunidade ou em pura equidade, é fundamental que possuam profundo conhecimento

14 BRASIL. Código de Processo Civil (Lei 13.105, de 16 de março de 2015). Disponível em: $<$ http://www.planalto.gov.br/ccivil_03/_Ato2015-2018/2015/Lei/L13105.htm>. Acesso em: 09 jun. 2015.

${ }^{15}$ GRECO, Leonardo. Op. cit., p. 5.

${ }^{16}$ GRECO, Leonardo. Op. cit., p. 5.

${ }^{17}$ Cf. 12 da Lei n ${ }^{\circ}$ 2556, de 21 de maio de 1996, do Estado do Rio de Janeiro, RIO DE JANEIRO (Estado). Lei $\mathrm{n}^{\mathrm{o}}$ 2.556, de 21 de maio de 1996. Disponível em: $<$ http://alerjln1.alerj.rj.gov.br/contlei.nsf/c8aa0900025feef6032564ec0060dfff/c3673b92b1 caf6b6032564f80 07cc6fc?OpenDocument>. Acesso em: 15 out. 2014. No mesmo sentido, o art. 13 da Resolução n. ${ }^{\circ}$ 174/2013 do Conselho Nacional de Justiça estabelece que: "Não obstante submetidos a procedimento de seleção, os juízes leigos poderão ser suspensos ou afastados de suas funções, ad nutum". BRASIL. Conselho Nacional de Justiça. Resolução no 174, de 12 de abril de 2013. Brasília, DF. Disponível em: <http://www.cnj.jus.br/atosadministrativos/atos-da-presidencia/resolucoespresidencia/24281-resolucao-n-174-de-12-de-abril-de-2013>. Acesso em: 20 out. 2014. 
Revista Eletrônica de Direito Processual - REDP. Volume 16. Julho a dezembro de 2015

Periódico Semestral da Pós-Graduação Stricto Sensu em Direito Processual da UERJ

Patrono: José Carlos Barbosa Moreira. ISSN 1982-7636. pp. 449-477

http://www.e-publicacoes.uerj.br/index.php/redp/index

jurídico para que possam aplicar, de forma adequada, as normas jurídicas vigentes, quer no

que se refere ao direito material, quer no que concerne ao direito processual ${ }^{18}$. Tanto é assim, que a Resolução n. ${ }^{\circ}$ 174/2013, do Conselho Nacional de Justiça exige que os Tribunais de Justiça providenciem capacitação adequada aos juízes leigos, tanto antes do início de suas atividades, por meio de curso de formação, quanto ao longo do exercício de sua função, de forma periódica e sempre gratuita ${ }^{19}$.

$\mathrm{O}$ at. $7^{\circ}$ da Lei 9.099/1995 estabelece que os juízes leigos dos Juizados Especiais Cíveis devem ser recrutados, preferentemente, entre advogados com mais de cinco anos de experiência ${ }^{20}$. Já o art. $15, \S 1^{\circ}$, da Lei 12.153/2009 dispõe que os juízes leigos dos Juizados

18 Assim, não concordamos com Alexandre Câmara, segundo o qual: “A imensa maioria dos casos que são submetidos ao Judiciário (e não só aos Juizados Especiais Cíveis) pode ser resolvida com base no senso jurídico comum do povo. Figure-se, por exemplo, a hipótese em que um motorista, em alta velocidade, avança um sinal e atropela um pedestre que atravessava a rua sobre a faixa de pedestres. Qualquer leigo é, certamente, capaz de dizer que o causador do acidente tem o dever de indenizar os prejuízos que causou. É muito pequeno, certamente, o número de casos submetidos ao Poder Judiciário em que a decisão depende, para ser boa, de profundo conhecimento jurídico. Talvez casos envolvendo fusão e incorporação de sociedades anônimas, ou aqueles em que se discute alguma sofisticada questão constitucional, entre alguns outros, exijam um conhecimento jurídico mais profundo, que apenas os profissionais habilitados possuem. De um modo geral, pois, é perfeitamente possível a um leigo julgar causas mais simples.

Consequência disso é que nos Juizados Especiais Cíveis, em que são submetidas a julgamento causas de pequeno valor ou de pequena complexidade, a atuação do juiz leigo pode ser extremamente útil. Além de decidir os casos que lhes sejam submetidos, os juízes leigos ajudariam, certamente (e ajudam onde já atuam), a desafogar os juízes togados, cercados por todos os lados por processos que, na maioria das vezes, dirigem-se a um desfecho a que se chegaria independentemente da presença do magistrado profissional.

Equivocou-se, porém, o legislador, ao exigir que o juiz leigo seja escolhido preferentemente entre advogados com mais de cinco anos de experiência. Estes advogados jamais poderiam ser qualificados como leigos. A figura do juiz leigo remete à pessoa comum do povo, sem conhecimento jurídico especializado, mas com o senso jurídico comum suficiente para resolver as causas mais simples. De toda sorte, como a lei estabelece que a escolha recairá preferentemente sobre advogados, nada impede que pessoas sem essa qualificação exerçam a função de juízes leigos”. CÂMARA, Alexandre Freitas. Juizados Especiais Cíveis Estaduais e Federais: Uma Abordagem Crítica. 1. ed. Rio de Janeiro: Lumen Juris, 2007, p. 57.

${ }^{19} \mathrm{O}$ art. $3^{\circ}$ da Resolução n. ${ }^{\circ}$ 174/2013, do Conselho Nacional de Justiça estabelece que: "O exercício das funções de juiz leigo [...] pressupõe capacitação anterior ao início das atividades". Já o art. $4^{\circ}$ da mesma resolução dispõe que: "Os Tribunais de Justiça deverão providenciar capacitação adequada, periódica e gratuita a seus juízes leigos, facultando-se ao interessado obter a capacitação junto a cursos reconhecidos pelo Tribunal de Justiça da respectiva unidade da federação, preferencialmente por meio das escolas de formação. Parágrafo único. Os Tribunais de Justiça deverão providenciar a capacitação de seus juízes leigos, no mínimo por 40 horas, observado o conteúdo programático mínimo estabelecido no Anexo I desta Resolução". O Anexo I da referida resolução estabelece o seguinte conteúdo programático mínimo para o curso de formação de juízes leigos: "I - PARTE TEÓRICA: 1. Juizados Especiais - Noções Gerais; 2. Direito do Consumidor, Direito Civil, Direito Penal, Direito Administrativo e/ou Constitucional aplicado aos Juizados Especiais; 3. Ética; 4. Jurisprudência das Turmas Recursais, Turmas de Uniformização e Tribunais Superiores; 5. Técnicas de Conciliação; 6. Audiência de instrução; 7. Técnica de Sentença Aplicada ao Sistema do Juizado Especial. II PARTE PRÁTICA: 1. Assistir audiências dos Juizados Especiais; 2. Debate e Estudo Dirigido sobre relatórios de observação de audiências". BRASIL. Conselho Nacional de Justiça. Resolução n ${ }^{\circ} 174$, de 12 de abril de 2013. Brasília, DF. Disponível em: <http://www.cnj.jus.br/atos-administrativos/atos-dapresidencia/resolucoespresidencia/24281-resolucao-n-174-de-12-de-abril-de-2013 > . Acesso em: 20 out. 2014. 20 BRASIL. Lei 9.099, de 26 de setembro de 1995. Disponível em: $<$ http://www.planalto.gov.br/ccivil_03/leis/19099.htm>. Acesso em: 15 out. 2014. 
Revista Eletrônica de Direito Processual - REDP. Volume 16. Julho a dezembro de 2015

Periódico Semestral da Pós-Graduação Stricto Sensu em Direito Processual da UERJ

Patrono: José Carlos Barbosa Moreira. ISSN 1982-7636. pp. 449-477 http://www.e-publicacoes.uerj.br/index.php/redp/index

Especiais da Fazenda Pública devem ser recrutados, preferentemente, entre advogados com mais de dois anos de experiência ${ }^{21}$.

$\mathrm{O}$ art. 12 da Lei 2.556/1996 do Estado do Rio de Janeiro dispõe que os juízes leigos dos Juizados Especiais Cíveis devem ser selecionados preferencialmente entre advogados, sem, contudo, fazer referência à prévia experiência profissional ${ }^{22}$. $\mathrm{O}$ art. 33, caput, da Lei 5.781/2010 do Estado do Rio de Janeiro dispõe no mesmo sentido quanto aos juízes leigos dos Juizados Especiais da Fazenda Pública ${ }^{23}$.

De qualquer forma, o art. $1^{\circ}$ da Resolução $n^{\circ}$ 174, de 12 de abril de 2013, do Conselho Nacional de Justiça impõe que os juízes leigos sejam recrutados entre advogados com mais de dois anos de experiência ${ }^{24}$, o que não fere a Constituição e, tampouco, a lei. O tempo de estágio não pode ser computado como experiência, ainda que o estagiário estivesse inscrito na $\mathrm{OAB}^{25}$. A referida exigência é razoável, pois o exercício da advocacia, pelo referido período, permite ao profissional do Direito fixar conceitos aprendidos em teoria, bem como vislumbrar problemas de ordem prática que, muitas vezes, não são adequadamente tratados pela doutrina e pela jurisprudência.

\section{Impedimento ao exercício da advocacia para o juiz leigo}

21 BRASIL. Lei 12.153, de 22 de dezembro de 2009. Disponível em: <http://www.planalto.gov.br/ccivil_03/_Ato2007-2010/2009/Lei/L12153.htm>. Acesso em: 01 nov. 2011.

22 RIO DE JANEIRO (Estado). Lei $\mathrm{n}^{\mathrm{o}}$ 2.556, de 21 de maio de 1996. Disponível em: < http://alerjln1.alerj.rj.gov.br/CONTLEI.NSF/e9589b9aabd9cac8032564fe0065abb4/c3673b92b1caf6b603256 4f8007cc6fc $>$. Acesso em: 15 out. 2014.

23 RIO DE JANEIRO (Estado). Lei $\mathrm{n}^{\mathrm{o}}$ 5.781, de 01 de julho de 2010. Disponível em: $<$ http://alerjln1.alerj.rj.gov.br/CONTLEI.NSF/e9589b9aabd9cac8032564fe0065abb4/289671a6e642c515832 5775f0057e2e0?OpenDocument>. Acesso em: 20 out. 2014.

${ }^{24}$ BRASIL. Conselho Nacional de Justiça. Resolução n 174, de 12 de abril de 2013. Brasília, DF. Disponível em: <http://www.cnj.jus.br/atos-administrativos/atos-da-presidencia/resolucoespresidencia/24281-resolucaon-174-de-12-de-abril-de-2013>. Acesso em: 20 out. 2014.

${ }^{25}$ Nesse sentido, o Superior Tribunal de Justiça já decidiu que: “O art. $7^{\circ}$ da Lei n. 9.099/1995 prevê que o candidato seja advogado inscrito de forma definitiva há mais de cinco anos na OAB, para que possa pleitear o encargo de juiz leigo do juizado especial estadual. Dessarte, não há como computar, nesse tempo, a atuação do candidato como estagiário, mesmo que assim inscrito nos quadros da Ordem (art. $3^{\circ}$, § $2^{\circ}$, da Lei n. 8.906/1994). Relembre-se que os atos de estagiário inscrito na $\mathrm{OAB}$ só terão validade se praticados em conjunto com advogado devidamente habilitado que fique responsável por eles. $\mathrm{O}$ fato de o edital ser vago quanto a essa inscrição definitiva não pode afastar os ditames da referida lei. Também não há falar em ofensa ao princípio da proporcionalidade se impossível a comparação entre as exigências previstas para o citado concurso, um recrutamento tido por simplificado, e a série de critérios referentes ao ingresso na magistratura no cargo de juiz substituto (vide art. 93, I, da CF, alterado pela EC n. 45/2004, que exige três anos de prática jurídica). Note-se, por último, que a nova redação do dispositivo constitucional não revogou o art. $7^{\circ}$ da Lei n. 9.099/1995, que ainda se encontra em consonância com os preceitos constitucionais". BRASIL. Superior Tribunal de Justiça. RMS 24.147/PB da Quinta Turma, Rel. Min. Laurita Vaz, j. 22.3.2011, DJe 06/04/2011, Informativo n. ${ }^{\circ} 0467$ de 21 a 25 mar. 2011. Disponível em: <www.stj.juss.br>. Acesso em: 31 out. 2014. 
Revista Eletrônica de Direito Processual - REDP. Volume 16. Julho a dezembro de 2015

Periódico Semestral da Pós-Graduação Stricto Sensu em Direito Processual da UERJ

Patrono: José Carlos Barbosa Moreira. ISSN 1982-7636. pp. 449-477 http://www.e-publicacoes.uerj.br/index.php/redp/index

O art. $7^{\circ}$, parágrafo único, da Lei 9.099/1995, estabelece que, os juízes leigos que sejam, também, advogados "ficarão impedidos de exercer a advocacia perante os Juizados Especiais, enquanto no desempenho de suas funções" ${ }^{26}$. A esse respeito, parte da doutrina defende que o advogado somente é impedido de exercer a advocacia no juizado em que atua como juiz leigo, não estando impedido de advogar nos demais juizados ${ }^{27}$. Este entendimento, contudo, não se sustenta, pois o que o legislador quis evitar, ao proibir o juiz leigo de advogar em quaisquer juizados especiais, foi justamente o mútuo favorecimento, a troca de favores, nas decisões, entre advogados que atuam como juízes leigos em diferentes juizados. Não obstante, o art. $6^{\circ}$ da Resolução nº 174/2013, do Conselho Nacional de Justiça foi mais permissivo do que a lei ao estabelecer que: “O juiz leigo não poderá exercer a advocacia no Sistema dos Juizados Especiais da respectiva Comarca, enquanto no desempenho das respectivas funções" ${ }^{28}$, sendo, portanto, ilegal. Assim, neste caso, deve prevalecer o art. $7^{\circ}$, parágrafo único, da Lei 9.099/1995 que proibiu o exercício da advocacia ao juiz leigo nos Juizados Especiais Cíveis de todo o território nacional.

A norma do art. $7^{\circ}$, parágrafo único, da Lei 9.099/1995 traz norma posterior e mais específica do que aquelas dos incisos II e IV do art. 28, da Lei 8.904/1994, razão pela qual somente a primeira se aplica aos juízes leigos. Assim, estes não estão impedidos de exercer a advocacia perante outros órgãos jurisdicionais ou administrativos ${ }^{29}$.

\footnotetext{
26 BRASIL. Lei 9.099, de 26 de setembro de 1995. Disponível em: $<$ http://www.planalto.gov.br/ccivil_03/leis/19099.htm>. Acesso em: 01 nov. 2014.

${ }^{27}$ Nesse sentido, Alexandre Câmara sustenta que: "o juiz leigo que seja advogado fica impedido de exercer a advocacia perante o mesmo Juizado Especial Cível em que atua (art. $7^{\circ}$, parágrafo único, da Lei ng 9.099/95), mas não perante outros Juizados Especiais Cíveis, como o texto da lei dá a entender". CÂMARA, Alexandre Freitas. Op. cit., p. 57. O mesmo entendimento é adotado por PINHO, Humberto Dalla Bernardina de. PINHO, Humberto Dalla Bernardina de. Direito Processual Civil Contemporâneo. 4 ed. São Paulo: Saraiva, 2012. 2v. V.1: Teoria Geral do Processo, p. 652. No mesmo sentido, dispõe o Enunciado n. ${ }^{\circ} 40$ do Fórum Nacional de Juizados Especiais (FONAJE), in verbis: "O conciliador ou juiz leigo não está incompatibilizado nem impedido de exercer a advocacia, exceto perante o próprio Juizado Especial em que atue ou se pertencer aos quadros do Poder Judiciário". BRASIL. Enunciado n. 40 do Fórum Nacional de Juizados Especiais (FONAJE). Disponível em: <http://www.fonaje.org.br/site/enunciados/>. Acesso em: 18 out. 2014.

${ }^{28}$ BRASIL. Conselho Nacional de Justiça. Resolução nº 174, de 12 de abril de 2013. Brasília, DF. Disponível em: <http:/www.cnj.jus.br/atos-administrativos/atos-da-presidencia/resolucoespresidencia/24281-resolucaon-174-de-12-de-abril-de-2013>. Acesso em: 20 out. 2014.

${ }^{29}$ SODRÉ, Eduardo. Juizados Especiais Cíveis: Processo de Conhecimento. 1. ed. Rio de Janeiro: Lumen Juris, 2005, p. 26. No mesmo sentido, Danilo Alejandro Mognoni Costalunga entende ser: "[...] possível a coexistência e compenetração das Leis n. ${ }^{\circ}$ 9.099/95 e 8.906/94, sem que com isso possamos causar a ruptura no sistema. O que os incisos II e IV do art. 28 da Lei n2 8.906/94 fixam é a norma geral sobre as atividades que tornam incompatível o exercício da advocacia Essa norma deverá ter aplicação sempre que não houver norma especial determinado regime diferente, como decorre da disposição do parágrafo único, do art. $7 .^{\circ}$, da Lei n. ${ }^{\circ}$ 9.099/95, que, seguramente, não determina incompatibilidade entre ambas as normas, e, além disso, nos
} 
Revista Eletrônica de Direito Processual - REDP. Volume 16. Julho a dezembro de 2015

Periódico Semestral da Pós-Graduação Stricto Sensu em Direito Processual da UERJ

Patrono: José Carlos Barbosa Moreira. ISSN 1982-7636. pp. 449-477 http://www.e-publicacoes.uerj.br/index.php/redp/index

\section{Conciliação conduzida por juiz leigo}

O art. 22 da Lei 9.099/1995 estabelece que "a conciliação será conduzida pelo juiz togado ou leigo ou por conciliador sob sua orientação". Entretanto, "não é necessária a presença do juiz togado ou leigo na sessão de conciliação" ${ }^{30}$, bastando que o conciliador possa se comunicar, por qualquer meio idôneo, com o juiz togado ou leigo no curso da audiência de conciliação que dirige, com o fim de tirar quaisquer dúvidas jurídicas que possam surgir.

Interessante observar que o Enunciado Administrativo n. ${ }^{\circ} 1.8$ do Aviso n. ${ }^{\circ} 23$ de 2008 do Presidente do Tribunal de Justiça do Estado do Rio de Janeiro faz a seguinte recomendação: "Deve-se evitar que o juiz leigo presida a audiência de conciliação prevista no artigo $53, \S 1^{\circ}$, da Lei n. ${ }^{\circ}$ 9.099/95" 31 . Concordamos com o enunciado, pois, uma vez liberado das audiências de conciliação, que devem ser conduzidas por conciliador devidamente preparado, o juiz leigo, concursado e, em regra, advogado, poderá dedicar seu tempo a tarefas que o conciliador não pode realizar: a condução de instruções probatórias e a elaboração de projetos de sentença, o que amplia consideravelmente a eficiência do Juizado Especial Cível.

autoriza a reconhecer um nexo coerente estável entre essas duas normas, ratificado pelo relevante fundamento social da nova disposição”. COSTALUNGA, Danilo Alejandro Mognoni. Sobre o exercício da advocacia por juízes leigos dos juizados especiais: para uma superação do conflito aparente de normas entre a Lei n. ${ }^{\circ} 8.906 / 94$ e a Lei n. ${ }^{\circ}$ 9.099/95. COSTALUNGA, Danilo Alejandro Mognoni. Sobre o exercício da advocacia por juízes leigos dos Juizados Especiais. Jus Navigandi, Teresina, ano 4, n. 31, 1 maio 1999, p. 2. Disponível em: $<$ http://jus.com.br/artigos/825>. Acesso em: 19 out. 2014. Ainda neste sentido, Felippe Borring Rocha leciona que: "Não se trata, como chegou a ser ventilado, de hipótese de incompatibilidade para o exercício da advocacia em geral, por aplicação extensiva do art 28, II, da Lei n. ${ }^{\circ}$ 8.906, de 4 de julho de 1994 (Estatuto da Advocacia). O preceito legal estabelece apenas um impedimento específico.

Não obstante, uma vez que o legislador não fez distinção, entendemos que a restrição se projeta por todos os juizados especiais dentro do Estado membro correspondente, sejam cíveis ou criminais, pois seria no mínimo ilógico pensar que um juiz leigo estaria impedido de advogar apenas perante o juizado em que atua, mas o possa fazer no juizado ao lado". ROCHA, Felippe Borring. Juizados Especiais Cíveis: Aspectos Polêmicos da Lei n. ${ }^{o} 9.099$ de 26/9/1995. 4. ed. Rio de Janeiro: Lumen Juris, 2005, p. 56. Nesse sentido, cf., ainda, PINHO, Humberto Dalla Bernardina de. Op.cit., p. 652.

${ }^{30}$ Nesse sentido, cf. BRASIL. Enunciado n. ${ }^{\circ} 6$ do Fórum Nacional de Juizados Especiais (FONAJE). . Disponível em: <http://www.fonaje.org.br/site/enunciados/>. Acesso em: 18 out. 2014.

${ }^{31}$ RIO DE JANEIRO (Estado). Tribunal de Justiça. Enunciado Administrativo n. ${ }^{\circ} 1.8$ do Aviso n. ${ }^{\circ} 23$ de 2008 do Presidente do Tribunal de Justiça do Estado do Rio de Janeiro. Disponível em: $<$ http://www.tjrj.jus.br/institucional/juiz_especiais/documentos/pdf/aviso23-2008.pdf $>$. Acesso em: 18 out. 2014. 
Revista Eletrônica de Direito Processual - REDP. Volume 16. Julho a dezembro de 2015

Periódico Semestral da Pós-Graduação Stricto Sensu em Direito Processual da UERJ

Patrono: José Carlos Barbosa Moreira. ISSN 1982-7636. pp. 449-477 http://www.e-publicacoes.uerj.br/index.php/redp/index

\section{A instrução probatória conduzida por juiz leigo}

O art. 37, da Lei 9.099/1995 estabelece que o juiz leigo pode dirigir a instrução probatória, no procedimento sumaríssimo dos juizados especiais cíveis, sob a supervisão do juiz togado ${ }^{32}$. Assim, embora o juiz leigo possa tomar decisões em matéria probatória, admitindo ou inadmitindo as provas requeridas pelas partes ou mesmo produzindo provas de ofício, todas as suas decisões estão sujeitas à revisão do juiz togado. Por esta razão, o art. 37, da Lei 9.099/1995 não viola a garantia constitucional do juiz natural, segundo a qual somente o juiz togado, de juízo previamente existente à lide, competente segundo a Constituição e lei, pode proferir as decisões interlocutórias que se façam necessárias em

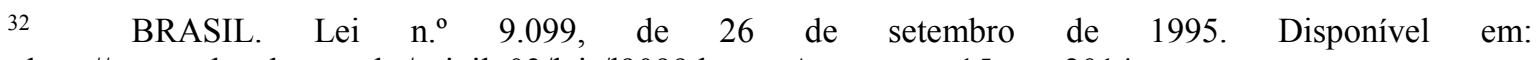
$<$ http://www.planalto.gov.br/ccivil_03/leis/19099.htm>. Acesso em: 15 out. 2014. 
Revista Eletrônica de Direito Processual - REDP. Volume 16. Julho a dezembro de 2015

Periódico Semestral da Pós-Graduação Stricto Sensu em Direito Processual da UERJ

Patrono: José Carlos Barbosa Moreira. ISSN 1982-7636. pp. 449-477

http://www.e-publicacoes.uerj.br/index.php/redp/index

determinado processo ${ }^{33}$, até porque não autoriza o juiz togado a delegar ao juiz leigo o poder

de proferi-las ${ }^{34}$.

O art. 10 da Resolução n. ${ }^{\circ}$ 174/2013, do Conselho Nacional de Justiça não impõe ao

juiz togado o dever de estar presente na audiência de instrução e julgamento dirigida pelo

juiz leigo, mas, tão somente, o dever de estar presente na sede do juizado, durante a referida

audiência, para que possa esclarecer eventuais dúvidas quer do juiz leigo, quer das partes ou

de seus advogados, sobre o direito aplicável ${ }^{35}$. Desta forma, prejudica seriamente o princípio

33 O princípio do juiz natural é consagrado pelo art.5, LIII, CF/1988, que dispõe, in verbis: "Ninguém será processado nem sentenciado senão pela autoridade competente”. BRASIL. Constituição da República $\begin{array}{llllll}\text { Federativa do } & \text { Brasil } & \text { de } & \text { Disponível }\end{array}$ $<$ http://www.planalto.gov.br/ccivil_03/Constituicao/Constituicao.htm>. Acesso em: 26 out. 2014. Cândido Rangel Dinamarco observa que a garantia do juiz natural é caracterizada pelo seguinte trinômio, no que concerne ao processo civil: “a) julgamentos por juiz e não por outras pessoas ou funcionários; b) preexistência do órgão judiciário, sendo vedados, também para o processo civil, eventuais tribunais de exceção instituídos depois de configurado o litígio; c) juiz competente segundo a Constituição e a lei”. O autor afirma, ainda, que: "A exigência de que os julgamentos se façam por juiz como tal indicado na Constituição impede que os valores da pessoa, patrimônio inclusive, fiquem expostos a medidas imperativas e definitivas ditadas por órgãos não qualificados a isso e, portanto, sem a aura de imparcialidade e sem as garantias de idoneidade que caracterizam a Magistratura. Não se excluem, obviamente, os julgamentos feitos pela Administração, seja em sede disciplinar ou no trato de interesses de outras pessoas ou entidades, como é o julgamento das licitações públicas. O processo e julgamento que a garantia do juiz natural manda fazer exclusivamente por juízes que conduzem ao final enforcing power, sem sujeição são aqueles a novas apreciações e censura por outros órgãos. Os atos da Administração, mesmo quando consistentes naqueles julgamentos, são sujeitos ao controle pelos juizes ao menos pelo aspecto da legalidade (Súmula $473 \mathrm{STF}$ ) - e tal é uma imposição e desdobramento do princípio da inafastabilidade do controle jurisdicional. Os julgamentos resultantes do controle jurisdicional é que se prestam a essa definitividade caracterizada como coisa julgada, ficando em tese imunes a qualquer questionamento ulterior. A Constituição dá corpo à garantia de ser julgado exclusivamente por juiz, ao elencar taxativamente os organismos judiciais do país, aptos portanto a serem o juiz natural das causas que vierem a julgamento. Trata-se do Supremo Tribunal Federal, Superior Tribunal de Justiça e tribunais e juízos inferiores de todas as Justiças (Eleitoral, do Trabalho, Militar, Federal, Estaduais comuns e Estaduais militares onde houver - art. 92), aos quais se acrescem os juizados especiais (art. 98, inc. I); a própria Constituição autoriza que se incluam juízes leigos, sem concurso portanto e não-vitalícios, competentes para a instrução das chamadas causas de menor complexidade e para proferir sentenças sujeitas a homologação pelo juiz togado (Const., art. 98, inc. I; lei n. 9.099, de 26.9.95, arts. 72, 22, 24, § 2-Q, 37 e 40); eles não exercem jurisdição, mas mera atividade parajurisdicional (infra, nn. 364 e 519). Os juízes de paz, também definidos na Constituição Federal (art. 98 , inc. II), não exercerão jurisdição alguma e limitar-se-ão à conciliação e atividades relacionadas com a habilitação para o casamento e sua celebração". DINAMARCO, Cândido Rangel. Instituições de Direito Processual Civil. São Paulo: Malheiros Editores. 6. ed. 4 v. V. 1, p. 209-210.

${ }^{34}$ Cândido Rangel Dinamarco assevera que: "Da impessoalidade no exercício da jurisdição decorre também que as competências não podem ser delegadas, uma vez que o poder de julgar não pertence à pessoa do juiz, mas ao Estado - cumprindo a este, mediante a legislação pertinente, atribuir o exercício da jurisdição aos ocupantes dos cargos ali indicados. A Constituição Federal não exclui de modo explícito a delegabilidade, mas a indelegabilidade é coessencial ao regime de competências traçado por ela própria e pela lei, sendo inerente à garantia constitucional do juiz natural (supra, n. 82). São portanto legítimas as proibições de delegar funções, contidas em Constituições estaduais”. DINAMARCO. Op. cit., p. 337.

35 "Art. 10. Ao magistrado da unidade incumbe o dever de fiscalizar e coordenar o trabalho de juízes leigos, devendo estar presente na unidade do Juizado Especial durante a realização das audiências". BRASIL. Conselho Nacional de Justiça. Resolução $n^{\circ}$ 174, de 12 de abril de 2013. Brasília, DF. Disponível em: $<$ http://www.cnj.jus.br/atos-administrativos/atos-da-presidencia/resolucoespresidencia/24281-resolucao-n174-de-12-de-abril-de-2013>. Acesso em: 20 out. 2014. 
Revista Eletrônica de Direito Processual - REDP. Volume 16. Julho a dezembro de 2015

Periódico Semestral da Pós-Graduação Stricto Sensu em Direito Processual da UERJ

Patrono: José Carlos Barbosa Moreira. ISSN 1982-7636. pp. 449-477

http://www.e-publicacoes.uerj.br/index.php/redp/index

da oralidade ${ }^{36}$, que deve orientar o processo perante os Juizados Especiais, tendo em vista o

disposto no art. $2^{\circ}$ da Lei 9.099/1995, já que reduz consideravelmente: a imediatidade, isto

é, o contato direto das partes com o juiz togado; a concentração dos atos processuais, posto que o juiz togado tenderá a proferir a sentença de homologação do projeto do juiz leigo fora da audiência de instrução e julgamento; a identidade física do juiz, pois o juiz togado encarregado de proferir a sentença não terá assistido à produção das provas orais na audiência de instrução e julgamento; e a irrecorribilidade das decisões interlocutórias, pois as partes sempre poderão requerer ao juiz togado a revisão das decisões tomadas pelo juiz leigo em matéria de prova, ainda que a lei não preveja recurso para tal fim.

A parte pode impugnar a decisão do juiz leigo que inadmitiu prova que pretendia produzir ou que admitiu prova requerida pelo adversário ou mesmo que determinou oficiosamente a produção de prova, peticionando oralmente ou por escrito ao juiz togado. Aqui se faz essencial o cumprimento, pelo juiz togado, do disposto no art. 35, IV, da

${ }^{36}$ Leonardo Greco aponta "como subprincípios da oralidade a imediatidade a concentração, a identidade física do juiz e a irrecorribilidade das decisões interlocutórias.

A imediatidade é uma consequência direta da oralidade. De nada adianta os atos processuais serem orais se eles não forem praticados perante o próprio juiz. Então, quando a lei estabelece a realização de audiências ou a realização de atos orais, como a inquirição de testemunhas, a tornada dos depoimentos pessoais das partes, as alegações finais orais dos advogados, eles têm de ser praticados na presença do juiz.. o juiz que deve presidir os atos orais,porque a oralidade é mais expressiva do que a comunicação escrita, não compreendendo somente as palavras, mas também os gestos, as entonações e as imagens. Por essas razões, os atos orais têm de ser praticados na presença de quem vai julgá-los, porque nenhum registro escrito desses atos vai conseguir reproduzir todo o seu realismo. $\mathrm{O}$ juiz deve ter contato direto com as partes e com as provas.

A Lei n. 9.099/95, que dispõe sobre os juizados especiais, estabeleceu que a instrução pode ser dirigida por juiz leigo (art. 37), o que compromete gravemente a imediatidade e, consequentemente, a oralidade. A imediatidade é fundamental ao diálogo humano [...].

A concentração prega a convergência de todos os atos orais em uma única audiência, ou, quando isso não seja possível, que todas as audiências sejam realizadas num curtíssimo intervalo de tempo. A concentração de atos orais, como a tentativa de conciliação, a tomada dos depoimentos e as alegações finais orais dos advogados, coloca o juiz numa posição privilegiada, na medida em que a sua cognição foi amplamente enriquecida pelo contato humano. Além disso, durante o período de tempo correspondente à audiência, ele não desviou sua atenção para nenhum outro processo; concentrou-se na realização daqueles atos orais, em tirar deles o maior proveito possível. Dessa forma, quando o magistrado chega ao término dessa audiência, ele está numa posição ideal para proferir uma boa sentença. [...]

A identidade física do juiz é o princípio segundo o qual o juiz que iniciou a instrução oral em audiência deve concluí-la e dar a sentença. A identidade física do juiz torna a oralidade eficaz, porque de nada adiantaria um juiz presidir os atos orais e outro dar a sentença ou juízes diferentes presidirem atos orais sucessivos. [...]

A irrecorribilidade das decisões interlocutórias foi sustentada por Chiovenda, porque o processo deveria ser concentrado, chegando rapidamente à audiência. Nessa audiência; na presença das partes, o juiz deveria estar em condições de rever todas as decisões que ele tivesse proferido anteriormente. Essa proposta de Chiovenda dependia de que o processo chegasse rapidamente ao seu momento culminante, que é a audiência final, e de que todas as decisões proferidas anteriormente não precluíssem, para que o juiz pudesse, na audiência oral, com urna cognição mais perfeita decorrente da oralidade e do diálogo humano, rever tudo". GRECO, Leonardo. Op. cit., p. 471-472. 
Revista Eletrônica de Direito Processual - REDP. Volume 16. Julho a dezembro de 2015

Periódico Semestral da Pós-Graduação Stricto Sensu em Direito Processual da UERJ

Patrono: José Carlos Barbosa Moreira. ISSN 1982-7636. pp. 449-477 http://www.e-publicacoes.uerj.br/index.php/redp/index

LOMAN $^{37}$ e no art. $7^{\circ}$, VIII, da Lei 8.906/1994 ${ }^{38}$, devendo o juiz receber o advogado da parte ou a própria parte, nos casos em que esta não estiver representada por advogado ${ }^{39}$, em seu gabinete, para decidir, de imediato, a impugnação contra a decisão do juiz leigo em matéria de prova. O juiz togado deve avaliar a correção das decisões do juiz leigo em matéria de prova, independentemente de requerimento das partes, ao ler o projeto de sentença elaborado por este, o que deverá necessariamente fazer para decidir pela homologação ou não do mencionado projeto, por meio de sentença ${ }^{40}$. Caso venha a constatar que alguma decisão probatória do juiz leigo é inadequada, o juiz togado deverá substituí-la por outra, determinando a produção da prova indeferida pelo juiz leigo ou anulando a prova ilícita aceita por este. Assim, não existe preclusão quanto às decisões tomadas pelo juiz leigo, até porque não existe a possibilidade de interpor agravo, ou qualquer outro recurso, quanto a $\operatorname{estas}^{41}$. Embora a parte possa impugnar a decisão proferida pelo juiz leigo, em matéria de prova, peticionando oralmente ao juiz togado, durante a audiência de instrução e julgamento, nada impede que ela venha a impugnar a referida decisão, posteriormente, por meio de petição escrita ao juiz togado, já que não ocorre prescrição.

\section{O projeto de sentença do juiz leigo e a sentença do juiz togado que o homologa}

O art. 203, caput, e $\S 1^{\circ}$, do CPC/2015 dispõe que:

\footnotetext{
37 “Art. 35 - São deveres do magistrado: [...] IV - [...] atender aos que o procurarem, a qualquer momento, quanto se trate de providência que reclame e possibilite solução de urgência". BRASIL. Lei Orgânica da Magistratura Nacional (Lei Complementar n. ${ }^{\circ}$ 35, de 14 de março de 1979). Disponível em: $<$ http://www.planalto.gov.br/ccivil_03/leis/lcp/lcp35.htm>. Acesso em: 18 out. 2014.

38 “Art. $7^{\circ}$ São direitos do advogado: [...] VIII - dirigir-se diretamente aos magistrados nas salas e gabinetes de trabalho, independentemente de horário previamente marcado ou outra condição, observando-se a ordem de chegada; [...]". BRASIL. Lei n. ${ }^{\circ}$ 8.906, de 4 de julho de 1994 . Disponível em: $<$ http://www.planalto.gov.br/ccivil_03/leis/18906.htm>. Acesso em: 18 out. 2014.

39 “Art. $9^{\circ}$ Nas causas de valor até vinte salários mínimos, as partes comparecerão pessoalmente, podendo ser assistidas por advogado; nas de valor superior, a assistência é obrigatória. [...]”. BRASIL. Lei n. ${ }^{\circ}$ 9.099, de 26 de setembro de 1995. . Disponível em: <http://www.planalto.gov.br/ccivil_03/leis/19099.htm>. Acesso em: 15 out. 2014.

${ }^{40}$ Cf. art. 40 da Lei 9.099/1995.

${ }^{41}$ Nesse sentido, Cândido Rangel Dinamarco assevera que: “[...] a ausência de preclusão a respeito das decisões proferidas em audiência mitigaria a gravidade do que fosse mal decidido pelo juiz leigo porque sempre, ao sentenciar, eventuais erros seriam corrigidos pelo togado (e não há preclusão porque não existe o agravo naqueles processos)". DINAMARCO, Cândido Rangel. Op. cit., p. 693.
} 
Revista Eletrônica de Direito Processual - REDP. Volume 16. Julho a dezembro de 2015

Periódico Semestral da Pós-Graduação Stricto Sensu em Direito Processual da UERJ

Patrono: José Carlos Barbosa Moreira. ISSN 1982-7636. pp. 449-477 http://www.e-publicacoes.uerj.br/index.php/redp/index

Art. 203. Os pronunciamentos do juiz consistirão em sentenças, decisões interlocutórias e despachos.

$\S 1^{\mathrm{o}}$ Ressalvadas as disposições expressas dos procedimentos especiais, sentença é o pronunciamento por meio do qual o juiz, com fundamento nos arts. 485 e 487, põe fim à fase cognitiva do procedimento comum, bem como extingue a execução.

No mesmo sentido, o art. 38, caput, da Lei 9.099/1995, referente aos juizados especiais, estabelece que "A sentença mencionará os elementos de convicção do Juiz [...]", donde se pode concluir que a sentença não pode ser proferida por qualquer pessoa que não seja um "juiz togado, magistrado por concurso e que goza das prerrogativas constitucionais da magistratura (ou, pelo menos, está em vias de conquistá-las, o que se dá quando o magistrado ainda está em período de vitaliciamento)" ${ }^{42}$. A sentença, portanto, é ato exclusivo do juiz togado.

O art. 40 da Lei 9.099/1995, entretanto, dispõe que "o Juiz leigo que tiver dirigido a instrução proferirá sua decisão e imediatamente a submeterá ao Juiz togado, que poderá homologá-la, proferir outra em substituição ou, antes de se manifestar, determinar a realização de atos probatórios indispensáveis". Ante o exposto, a decisão do juiz leigo não é uma sentença, mas, tão somente, um projeto de sentença ${ }^{43}$, que tem natureza parajurisdicional $^{44}$. Assim, o art. 40 da Lei 9.099/1995 não viola o princípio do juiz natural ${ }^{45}$ de acordo com o qual somente o juiz togado, de juízo previamente existente à lide, competente conforme a Constituição e a lei, pode proferir a sentença ${ }^{46}$, até porque não autoriza o juiz togado a delegar ao juiz leigo o poder de proferi-las. Da mesma forma, não afronta o princípio da inafastabilidade do controle jurisdicional, pois o projeto de sentença

\footnotetext{
${ }^{42}$ CÂMARA, Alexandre Freitas. Op. cit., p. 128.

${ }^{43}$ Nesse sentido, CÂMARA, Alexandre Freitas. Op. cit., p. 128.

${ }^{44}$ Nesse sentido, Cândido Rangel Dinamarco defende que: "Ao juiz leigo a lei especial outorga ainda a competência para proferir sentenças nos processos cuja instrução houver conduzido. Seu ato, contudo, só se integrará quando o homologar o juiz togado (art. 40). Antes disso, não entra eficazmente no mundo jurídico e, obviamente, não ficará imunizado pela coisa julgada material. A soma dos dois atos dá o perfil de um ato jurídico processual complexo, em que a consumada jurisdicionalização não se ocorre sem que ocorra o segundo deles. Mas o resultado desse ato complexo é autenticamente jurisdicional e o ato do juiz

leigo, havendo ficado a meio caminho da plenitude, é por isso de natureza parajurisdicional". DINAMARCO, Cândido Rangel. Op. cit., p. 693.

${ }^{45}$ Cf. art.5 ${ }^{\circ}$, LIII, CF/1988. Cf., ainda, DINAMARCO, Cândido Rangel. Op. cit., p. 208-213.

${ }^{46}$ DINAMARCO, Cândido Rangel. Op. cit., p. 337.
} 
Revista Eletrônica de Direito Processual - REDP. Volume 16. Julho a dezembro de 2015

Periódico Semestral da Pós-Graduação Stricto Sensu em Direito Processual da UERJ

Patrono: José Carlos Barbosa Moreira. ISSN 1982-7636. pp. 449-477

http://www.e-publicacoes.uerj.br/index.php/redp/index

elaborado pelo juiz leigo não produz qualquer efeito, mas, tão somente, a sentença do juiz

togado que o homologa. Por outro lado, o juiz togado pode deixar de homologar o projeto de sentença feito pelo juiz leigo, proferindo sentença em sentido diverso deste ${ }^{47}$.

O juiz leigo que houver presidido a instrução ${ }^{48}$ deve elaborar um projeto de sentença que será submetido ao juiz togado. Este deve avaliar, à vista do projeto de sentença, se as provas produzidas no processo são lícitas e suficientes à formação do seu convencimento, se as mesmas foram adequadamente valoradas e se o direito positivo foi corretamente aplicado pelo juiz leigo. Tendo aprovado o projeto, o juiz togado o homologará por sentença. Neste caso, o conteúdo da sentença homologatória será o projeto de sentença. Entretanto, caso o juiz togado constate que o juiz leigo não valorou as provas ou não aplicou o direito positivo de forma adequada, deixará de homologar o projeto de sentença, proferindo sentença que não se baseará neste. Caso, diante das provas produzidas no processo, que o projeto de sentença deve referir, o juiz togado não fique convencido da veracidade ou da inverdade das alegações de fato apresentadas pelas partes, determinará a produção das provas que considerar essenciais à formação de seu convencimento, antes de proferir a sentença ${ }^{49}$. Neste

\footnotetext{
${ }^{47}$ Assim, não assiste razão a Felippe Borring Rocha para quem: "preceitua o legislador que o juiz leigo poderá [...] proferir sentença (art. 40). Cuida-se de flagrante afronta aos princípios constitucionais da inafastabilidade da apreciação pelo Poder Judiciário de lesão ou ameaça de lesão e do juiz natural, respectivamente, art. $5^{\circ}$, XXXV e LIII, da CF". ROCHA, Felippe Borring. Juizados Especiais Cíveis: Aspectos Polêmicos da Lei n. ${ }^{\circ}$ 9.099 de 26/9/1995. 4. ed. Rio de Janeiro: Lumen Juris, 2005, p. 55, e, tampouco a Humbero Dalla Bernardina de Pinho para quem "[...] os juízes leigos podem [...] proferir "decisão" sobre causa, inclusive de embargos do devedor (Enunciado 52 do Fonaje), sujeita à homologação ou substituição pelo juiz togado (art. 40).

Cuida-se, nesses dois últimos casos, de flagrante afronta aos princípios constitucionais da inafastabilidade da apreciação pelo Poder Judiciário de lesão ou ameaça de lesão e do juiz natural, previstos, respectivamente, no art. 5', XXXV e LIII, da CF”. PINHO, Humberto Dalla Bernardina de. Op. cit., p. 651652.

${ }^{48}$ Cf. art. 37, Lei 9.099/1995.

49 Nesse sentido, Alexandre Câmara leciona que: “Ao juiz de direito (togado, como diz a lei) cabe proferir sentença. O juiz leigo que preside a instrução probatória pode, apenas, proferir o que prefiro denominar projeto de sentença.

Tendo o juiz leigo presidido a instrução probatória (o que é possível em razão do disposto no art. 37 da Lei n. ${ }^{\circ}$ 9.099/95), caberá a ele elaborar um projeto de sentença. Este projeto é imediatamente submetido ao juiz togado que, se com ele concordar, o homologa por sentença. A homologação é o ato do juiz (de natureza sentenciai) que adota como conteúdo o ato homologado (ou seja, no caso ora em exame, o projeto de sentença elaborado pelo juiz leigo). E o fenômeno que se dá, por exemplo, quando o juiz, por sentença, homologa urna transação. A sentença é o ato do juiz, mas o conteúdo desse ato é a transação das partes. Do mesmo modo, quando o juiz homologa o reconhecimento do pedido, o ato homologatório, praticado pelo juiz, é a sentença, e seu conteúdo é o reconhecimento do pedido manifestado pelo demandado.

Assim sendo, quando o juiz togado homologa o projeto de sentença do juiz leigo ter-se-á urna sentença (ato do juiz togado) cujo conteúdo é o projeto de sentença (ato do juiz leigo). A sentença, porém, terá de ser proferida pelo juiz togado, e é o ato deste que exerce, no processo, a função processual que à sentença cabe.

Pode o juiz togado, porém, não concordar com o projeto de sentença do juiz leigo. Neste caso, abremse para ele duas diferentes opções: proferir sentença com conteúdo distinto ou determinar a prática de outros
} 
Revista Eletrônica de Direito Processual - REDP. Volume 16. Julho a dezembro de 2015

Periódico Semestral da Pós-Graduação Stricto Sensu em Direito Processual da UERJ

Patrono: José Carlos Barbosa Moreira. ISSN 1982-7636. pp. 449-477 http://www.e-publicacoes.uerj.br/index.php/redp/index

momento, o juiz togado deve aferir a licitude das provas em que se baseou o projeto de sentença, devendo desconsiderá-las caso sejam ilícitas e, conforme o caso, proferir sentença com conclusão diversa da do projeto.

Tendo em vista o princípio constitucional da duração razoável do processo $^{50}$, o princípio da celeridade ${ }^{51}$, que deve nortear os juizados especiais, e o princípio da economia dos atos processuais, o juiz leigo deve seguir as orientações e o entendimento jurídico do juiz togado, único legalmente autorizado a exercer a jurisdição, ao elaborar o projeto de sentença ${ }^{52}$, até para que este possa ser homologado, evitando-se o proferimento de sentença em sentido diverso, o que prolonga o processo desnecessariamente.

O juiz leigo que presidiu a audiência de instrução e julgamento pode reconhecer a revelia, por meio de seu projeto de sentença, o qual será homologado pelo juiz togado de acordo com os artigos 23 e 40 da lei $9.099 / 95^{53}$.

O art. 11 da Resolução n. ${ }^{\circ}$ 174/2013, do Conselho Nacional de Justiça ${ }^{54}$ contribui para a duração razoável do processo ${ }^{55}$, para a celeridade processual $^{56}$ e para a operosidade ${ }^{57}$

atos probatórios, que lhe pareçam indispensáveis para a formação de seu convencimento e, só depois, proferir a sentença. Seja qual for a opção do juiz, porém, será sua a incumbência de proferir a sentença". CÂMARA, Alexandre Freitas. Op. cit., p. 128-129.

${ }^{50} \mathrm{Cf}$. art. $5^{\circ}$, LXXVIII, da Constituição Federal.

${ }^{51}$ Cf. art. $5^{\circ}$, LXXVIII, da Constituição Federal, in fine, e art. $2^{\circ}$, da Lei 9.099/1995.

${ }^{52}$ Nesse sentido dispõe o parágrafo único do art. 10, da Resolução n. ${ }^{\circ}$ 174/2013, do Conselho Nacional de Justiça, in verbis: "O juiz leigo fica subordinado às orientações e ao entendimento jurídico do juiz togado", bem como o art. $3^{\circ}$, XII, do Código de Ética do Juiz Leigo, Anexo II da referida resolução: "Art. $3^{\circ}$ São deveres dos juízes leigos [...]: XII - subordinar-se às orientações e ao entendimento jurídico do juiz togado". BRASIL. Conselho Nacional de Justiça. Resolução $\mathrm{n}^{\circ}$ 174, de 12 de abril de 2013. Brasília, DF. Disponível em: $<$ http://www.cnj.jus.br/atos-administrativos/atos-da-presidencia/resolucoespresidencia/24281-resolucao-n174-de-12-de-abril-de-2013>. Acesso em: 20 out. 2014.

${ }^{53}$ Nesse sentido, o Enunciado Administrativo n. ${ }^{\circ} 1.9$ do Aviso n. ${ }^{\circ} 23$ de 2008 do Presidente do Tribunal de Justiça do Estado do Rio de Janeiro dispõe que: "O juiz leigo pode elaborar projeto de sentença reconhecendo a revelia, o qual será homologado pelo juiz togado nos termos dos artigos 23 e 40 da lei 9099/95, desde que tenha presidido a AIJ". RIO DE JANEIRO (Estado). Tribunal de Justiça. Enunciado Administrativo n. ${ }^{\circ} 1.9$ do Aviso n. ${ }^{\circ} 23$ de 2008 do Presidente do Tribunal de Justiça do Estado do Rio de Janeiro. Disponível em: $<$ http://www.tjrj.jus.br/institucional/juiz_especiais/documentos/pdf/aviso23-2008.pdf $>$. Acesso em: 18 out. 2014.

${ }^{54}$ BRASIL. Conselho Nacional de Justiça. Resolução no 174, de 12 de abril de 2013. Brasília, DF. Disponível em: <http://www.cnj.jus.br/atos-administrativos/atos-da-presidencia/resolucoespresidencia/24281-resolucaon-174-de-12-de-abril-de-2013>. Acesso em: 20 out. 2014.

${ }^{55} \mathrm{Cf}$. art. $5^{\circ}$, LXXVIII, da Constituição Federal.

${ }^{56}$ Cf. art. $5^{\circ}$, LXXVIII, da Constituição Federal, in fine, e art. 2º da Lei 9.099/1995.

${ }^{57}$ Segundo Paulo Cezar Pinheiro Carneiro, entre os princípios que informam o acesso à justiça está o da operosidade. "Esse princípio significa que as pessoas, quaisquer que sejam elas, que participam direta ou indiretamente da atividade judicial ou extrajudicial, devem atuar da forma mais produtiva e laboriosa possível para assegurar o efetivo acesso à justiça. Assim, para atender aos fins preconizados nesse trabalho e que garantem, na prática, tal acesso, é indispensável: a) atuação ética de todos quantos participem da atividade judicial ou extrajudicial; b) utilização dos instrumentos e dos institutos processuais de forma a obter a melhor produtividade possível, ou seja, utilização da técnica a serviço dos fins idealizados". Quanto à atuação ética, 
Revista Eletrônica de Direito Processual - REDP. Volume 16. Julho a dezembro de 2015

Periódico Semestral da Pós-Graduação Stricto Sensu em Direito Processual da UERJ

Patrono: José Carlos Barbosa Moreira. ISSN 1982-7636. pp. 449-477 http://www.e-publicacoes.uerj.br/index.php/redp/index

do juiz leigo, ao exigir que este apresente seu projeto de sentença no prazo máximo de 10 dias a contar do encerramento da instrução. Entretanto a exigência deste mesmo artigo no sentido de que o projeto de sentença "só poderá ser entranhado aos autos e disponibilizado para o público externo no sistema de informática caso seja homologado" viola o art. $5^{\circ}$, inciso LX, da Constituição Federal, segundo o qual "a lei só poderá restringir a publicidade dos atos processuais quando a defesa da intimidade ou o interesse social o exigirem". Ora, segundo este dispositivo, somente a lei em sentido estrito pode restringir a publicidade dos atos processuais, nunca uma resolução. Por outro lado, a regra do art. 11 da Resolução n. ${ }^{\circ}$ 174/2013, do Conselho Nacional de Justiça não visa à proteção da intimidade ou do interesse social.

Para garantir que o juiz togado efetivamente leia o projeto de sentença elaborado pelo juiz leigo, não se limitando a assiná-lo, a lei deveria prever a designação de audiência especial para a leitura da sentença, em voz alta, pelo juiz togado ${ }^{58}$.

O projeto de sentença deve atender aos mesmos requisitos que o art. 93, IX, da Constituição Federal e o art. 38 da Lei 9.099/1995 impõe à sentença. Assim, deve ser devidamente fundamentado, mencionando os elementos de convicção do Juiz. Deve ainda trazer breve resumo dos fatos relevantes ocorridos na audiência de instrução e julgamento, sendo dispensado o relatório ${ }^{59}$.

O art. 40 da Lei 9.099/1995 não autoriza o juiz leigo a elaborar projeto de decisão interlocutória, como aquela que antecipa a tutela pleiteada pela parte. A "decisão" do juiz

destaca que: "todos devem cooperar com as atividades destinadas à democratização do processo, tendo como meta ideal a participação de quem quer que seja, em igualdade de condições, de sorte a possibilitar a justa composição dos conflitos individuais ou coletivos que surjam em determinada sociedade. Seria um absoluto contrassenso imaginar que os fins sociais e políticos que informam o processo como instrumento de realização de uma das funções essências do Estado pudessem ser alcançados sem que os operadores e cooperadores da justiça participem de forma correta, ética; daí porque, no momento em que qualquer um dos participantes dessa atividade atue de forma a prejudicar ou impossibilitar o alcance dos fins idealizados, ele estará tendo um comportamento inadequado, contrariando as normas éticas que informam aquele sistema jurídico". CARNEIRO, Paulo Cezar Pinheiro. Acesso à Justiça: juizados especiais cíveis e ação civil pública: uma nova sistematização da Teoria Geral do Processo. 2. ed. Rio de Janeiro: Forense, 2003, p. 55, 63-65.

${ }^{58} \mathrm{O}$ Enunciado n. ${ }^{\circ} 95$ do Fórum Nacional de Juizados Especiais (FONAJE) dispõe, in verbis: "Finda a audiência de instrução, conduzida por Juiz Leigo, deverá ser apresentada a proposta de sentença ao Juiz Togado em até dez dias, intimadas as partes no próprio termo da audiência para a data da leitura da sentença". BRASIL. Enunciado n. ${ }^{\circ} 40$ do Fórum Nacional de Juizados Especiais (FONAJE). Disponível em: $<$ http://www.fonaje.org.br/site/enunciados/>. Acesso em: 18 out. 2014. Note-se, contudo, que o enunciado não recomenda que a leitura da sentença seja feita pelo próprio juiz togado.

${ }^{59}$ SLAIB FILHO, Nagib. O Juiz leigo e o projeto de decisão referido no art. 40 da Lei no 9.099/95, p. 1. Disponível em: <http:/www.nagib.net/index.php/publicacoes/artigos/civil-processo-civil-consumidor/589div2>. Acesso em: 06 nov. 2014. 
Revista Eletrônica de Direito Processual - REDP. Volume 16. Julho a dezembro de 2015

Periódico Semestral da Pós-Graduação Stricto Sensu em Direito Processual da UERJ

Patrono: José Carlos Barbosa Moreira. ISSN 1982-7636. pp. 449-477 http://www.e-publicacoes.uerj.br/index.php/redp/index

leigo a que se refere este artigo é, tão somente, o projeto de sentença, já que o referido dispositivo está inserido na seção XII, do capítulo II da Lei 9.099/1995, intitulada "da sentença". Assim, quaisquer decisões interlocutórias que se façam necessárias no processo devem ser proferidas diretamente pelo juiz togado ${ }^{60}$.

\section{A arbitragem nos juizados especiais cíveis e o juiz leigo}

A Lei 9.099/1995 tratou da arbitragem no âmbito dos juizados especiais cíveis em seus artigos 24, 25 e 26. O art. 24 da Lei 9.099/1995 estabelece que "não obtida a conciliação, as partes poderão optar, de comum acordo, pelo juízo arbitral, na forma prevista nesta Lei” 61. A Lei 9.099/1995 foi elaborada antes da Lei 9.307/1996 ${ }^{62}$, que estabeleceu disposições gerais acerca da arbitragem. Apesar de ter tratado do tema da arbitragem de forma bem diferente e tecnicamente melhor ${ }^{63}$, a Lei 9.307/1996 não revogou os artigos da Lei 9.099/1995 que disciplinam a arbitragem nos juizados especiais cíveis, pois estes se referem à hipótese mais específica ${ }^{64}$.

A arbitragem é um meio de resolução dos conflitos de interesses alternativo à jurisdição, mas, tal como esta, é heterocompositivo, isto é, soluciona a contenda através da decisão de um terceiro que não é titular de nenhum dos interesses em questão. Contudo, enquanto no processo judicial, o Estado indica o juiz da causa, e a Constituição e a lei lhe outorgam o poder de julgar, na arbitragem, são as partes que selecionam a pessoa que decidirá seu conflito, o árbitro, conferindo a este o poder de julgar ${ }^{65}$.

A arbitragem, tal como disciplinada pela Lei 9.099/1995, é um instituto em desuso. Aquela prevista pela Lei 9.307/1996, por outro lado, é inacessível à grande maioria das pessoas em razão do alto valor dos honorários comumente cobrados pelos árbitros.

\footnotetext{
${ }^{60}$ Em sentido contrário, defendendo que o art. 40 da Lei 9.099/1995 autoriza o juiz leigo a elaborar projetos de decisões interlocutórias, SLAIB FILHO, Nagib. Op. cit., p. 1.

61 BRASIL. Lei n. ${ }^{\circ} 9.099$, de 26 de setembro de 1995. Disponível em: $<$ http://www.planalto.gov.br/ccivil_03/leis/19099.htm>. Acesso em: 19 out. 2014.

62 BRASIL. Lei n. ${ }^{\circ}$ 9.307, de 23 de setembro de 1996. Disponível em: $<$ http://www.planalto.gov.br/ccivil_03/Leis/L9307.htm>. Acesso em: 19 out. 2014.

${ }^{63}$ Em sentido semelhante, CÂMARA, Alexandre Freitas. Op. cit., p. 103.

${ }^{64}$ Nesse sentido, o $\S 2^{\circ}$ do art. $2^{\circ}$ da Lei de Introdução às normas do Direito Brasileiro dispõe que: "A lei nova, que estabeleça disposições gerais ou especiais a par das já existentes, não revoga nem modifica a lei anterior". BRASIL. Lei de Introdução às normas do Direito Brasileiro (Decreto-Lei n. ${ }^{\circ} 4.657$, de 4 de setembro de 1942). Disponível em: <http://www.planalto.gov.br/ccivil_03/Decreto-Lei/Del4657.htm>. Acesso em: 19 out. 2014. ${ }^{65}$ CÂMARA, Alexandre Freitas. Op. cit., p. 103.
} 
Revista Eletrônica de Direito Processual - REDP. Volume 16. Julho a dezembro de 2015

Periódico Semestral da Pós-Graduação Stricto Sensu em Direito Processual da UERJ

Patrono: José Carlos Barbosa Moreira. ISSN 1982-7636. pp. 449-477 http://www.e-publicacoes.uerj.br/index.php/redp/index

O art. 24, §2º da Lei 9.099/1995, restringe a liberdade das partes ao obrigá-las a escolher o árbitro dentre os juízes leigos. O art. 13, da Lei 9.307/1996, por sua vez, permite que as partes escolham como árbitro qualquer pessoa capaz para os atos da vida $\operatorname{civil}^{66}$.

O art. 19, caput, da Lei 9.307/1996 estabelece que a arbitragem é instituída "quando aceita a nomeação pelo árbitro, se for único, ou por todos, se forem vários" ${ }^{\$ 17}$, conferindo à pessoa escolhida pelas partes o direito de recusar a função de árbitro. Já o $§ 1^{\circ}$ do art. 24 , da Lei 9.099/1995, estabelece que “o juízo arbitral considerar-se-á instaurado, independentemente de termo de compromisso, com a escolha do árbitro pelas partes. Se este não estiver presente, o Juiz convocá-lo-á e designará, de imediato, a data para a audiência de instrução" ${ }^{68}$, impondo a função de árbitro ao juiz leigo escolhido pelas partes ${ }^{69}$.

$\mathrm{O}$ art. 21, caput, da Lei 9.307/1996 faculta às partes convencionar sobre o procedimento arbitral, podendo reportar-se às regras de um órgão arbitral institucional ou entidade especializada, ou delegar ao próprio árbitro, ou ao tribunal arbitral, regular o procedimento. Já a Lei 9.099/1995 fixa o rito a ser seguido na arbitragem, que envolve uma audiência de instrução, onde o demandado poderá oferecer sua resposta e serão produzidas as provas para que, em seguida, o árbitro profira sua decisão ${ }^{70}$.

O art. 25, da Lei 9.099/1995 confere ao árbitro os mesmos poderes do juiz em matéria probatória, além de autorizá-lo a decidir por equidade em qualquer caso ${ }^{71}$. Já no sistema da Lei 9.307/1996, o árbitro somente pode decidir por equidade se for expressamente autorizado pelas partes nesse sentido, devendo decidir com base no direito brasileiro positivo no silêncio destas ${ }^{72}$.

${ }^{66}$ CÂMARA, Alexandre Freitas. Op. cit., p. 104. Contudo, não concordamos com a assertiva de Alexandre Câmara, no sentido de que a Lei 9.307/1996 exige que o árbitro seja alfabetizado e conheça a língua portuguesa. 67 BRASIL. Lei n. ${ }^{\circ}$ 9.307, de 23 de setembro de 1996. Disponível em: $<$ http://www.planalto.gov.br/ccivil_03/Leis/L9307.htm>. Acesso em: 19 out. 2014.

68 BRASIL. Lei n. ${ }^{\circ} 9.099$, de 26 de setembro de 1995 . Disponível em: $<$ http://www.planalto.gov.br/ccivil_03/leis/19099.htm>. Acesso em: 19 out. 2014.

${ }^{69}$ CÂMARA, Alexandre Freitas. Op. cit., p. 104.

${ }^{70}$ CÂMARA, Alexandre Freitas. Op. cit., p. 104.

${ }^{71} \mathrm{O}$ art. 25, da Lei 9.099/1995 dispõe que: "O árbitro conduzirá o processo com os mesmos critérios do Juiz, na forma dos arts. $5^{\circ}$ e $6^{\circ}$ desta Lei, podendo decidir por equidade". $\mathrm{O}$ art. $5^{\circ}$ da mesma lei estabelece que: “O Juiz dirigirá o processo com liberdade para determinar as provas a serem produzidas, para apreciá-las e para dar especial valor às regras de experiência comum ou técnica". Já o art. 6º da lei 9.099/1995 dispõe que: “O Juiz adotará em cada caso a decisão que reputar mais justa e equânime, atendendo aos fins sociais da lei e às exigências do bem comum". BRASIL. Lei n. ${ }^{0}$ 9.099, de 26 de setembro de 1995. Disponível em: $<$ http://www.planalto.gov.br/ccivil_03/leis/19099.htm>. Acesso em: 19 out. 2014.

$72 \mathrm{O}$ art. $2^{\circ}$ da Lei 9.307/1996 estabelece que: "A arbitragem poderá ser de direito ou de equidade, a critério das partes”. O art. 11, da mesma lei, por sua vez dispõe que: “poderá [...] o compromisso arbitral conter: [...] II - a autorização para que o árbitro ou os árbitros julguem por equidade, se assim for convencionado pelas 
Revista Eletrônica de Direito Processual - REDP. Volume 16. Julho a dezembro de 2015

Periódico Semestral da Pós-Graduação Stricto Sensu em Direito Processual da UERJ

Patrono: José Carlos Barbosa Moreira. ISSN 1982-7636. pp. 449-477 http://www.e-publicacoes.uerj.br/index.php/redp/index

Finda a instrução, o árbitro deve apresentar sua decisão ao juiz togado em cinco $\operatorname{dias}^{73}$. Enquanto a Lei 9.307/1997 denomina “sentença arbitral” a decisão do árbitro ${ }^{74}$, sendo esta título executivo judicial, desde o momento em que é proferida ${ }^{75}$, o art. 26 da Lei 9.099/1995 denomina a referida decisão de "laudo" e exige que a mesma seja homologada por sentença do juiz togado para que se torne título executivo judicial. Da mesma forma, estabelece que a sentença homologatória do laudo arbitral é irrecorrível ${ }^{76}$.

\section{Embargos à execução de sentença, embargos à execução de título executivo extrajudicial e juiz leigo}

Por falta de previsão legal, o juiz leigo não pode elaborar projeto de decisão para os embargos à execução de sentença de que trata o art. 52, IX, da Lei 9.099/1995, e, tampouco, para os embargos à execução de título executivo extrajudicial, a que alude o art. $53, \S 1^{\circ}$, da Lei 9.099/1995 ${ }^{77}$.

\section{Natureza jurídica do juiz leigo}

partes". BRASIL. Lei n. ${ }^{\circ}$ 9.307, de 23 de setembro de 1996. Disponível em: $<$ http://www.planalto.gov.br/ccivil_03/Leis/L9307.htm>. Acesso em: 19 out. 2014.

${ }^{73}$ Cf. art. 26, da Lei 9.099/1995.

${ }^{74}$ Cf. arts. 10 , IV; 11, III; 22, $\S 3^{\circ} ; 23$, caput; 26; 27; 28; 29; 30; 31; 32; 33; 34; 35; 37; 38; e 39; todos da Lei 9.307/1996.

${ }^{75}$ Cf. art. 515, VII, CPC/2015.

76 BRASIL. Lei n. ${ }^{\circ}$ 9.099, de 26 de setembro de 1995. Disponível em: $<$ http://www.planalto.gov.br/ccivil_03/leis/19099.htm>. Acesso em: 19 out. 2014.

${ }^{77}$ Em sentido contrário, o Enunciado n. ${ }^{\circ} 52$ do Fórum Nacional de Juizados Especiais (FONAJE) dispõe que: "Os embargos à execução poderão ser decididos pelo juiz leigo, observado o art. 40 da Lei n 9.099/1995". Disponível em: <http://www.fonaje.org.br/site/enunciados/>. Acesso em: 18 out. 2014. 
Revista Eletrônica de Direito Processual - REDP. Volume 16. Julho a dezembro de 2015

Periódico Semestral da Pós-Graduação Stricto Sensu em Direito Processual da UERJ

Patrono: José Carlos Barbosa Moreira. ISSN 1982-7636. pp. 449-477 http://www.e-publicacoes.uerj.br/index.php/redp/index

$\mathrm{O}$ juiz leigo é um auxiliar ${ }^{78}$ parajurisdicional $^{79}$ da justiça, considerado funcionário

público para fins penais, por exercer função pública transitoriamente ${ }^{80}$.

O Estado responde objetivamente pelos danos que o juiz leigo, nessa qualidade, causar a terceiros, tendo direito de regresso contra o responsável nos casos de dolo ou culpa, por força do art. $37, \S 6^{\circ}$, da Constituição Federal.

No Estado do Rio de Janeiro, os juízes leigos estão sujeitos às normas disciplinares destinadas aos servidores da Justiça ${ }^{81}$.

O juiz leigo está sujeito aos motivos de impedimento ${ }^{82}$ e aos de suspeição ${ }^{83}$ a que se submete o juiz togado ${ }^{84}$, por tratar-se de serventuário da justiça ${ }^{85}$ e por ter poder de decisão ${ }^{86}$.

\section{O Princípio da cooperação e o juiz leigo}

\footnotetext{
${ }^{78} \mathrm{Cf}$. art. $7^{\circ}$, Lei 9.099/1995, no que concerne aos Juizados Especiais Cíveis; e art. 15, $\S 1^{\circ}$, Lei 12.153/2009 no que toca aos Juizados Especiais da Fazenda Pública. Cf., ainda, art. $1^{\circ}$ da Resolução n ${ }^{\circ}$ 174, de 12 de abril de 2013, do Conselho Nacional de Justiça.

${ }^{79}$ Segundo Cândido Rangel Dinamarco, "O conciliador, o juiz leigo e o árbitro, incluídos na sistemática do processo especialíssimo dos juizados especiais cíveis, têm funções que em alguma medida partilham da natureza da função jurisdicional e em parte coincidem com as dos auxiliares em geral - as quais eles exercem em regime de subordinação ao juiz e sem o caráter de definitividade que distingue a jurisdição. Daí serem parajurisdicionais as funções assumidas por esses auxiliares especialíssimos. Dos auxiliares permanentes eles têm a característica do exercício continuado, fazendo parte do esquema fixo dos juizados. Mas não são remunerados, como os auxiliares permanentes de feitio tradicional e como os auxiliares eventuais em geral. $\mathrm{O}$ conciliador e o juiz leigo são expressamente indicados como auxiliares da Justiça (lei n. 9.099, de 26.9.95, art. 79) e o árbitro será nomeado ad hoc entre os juízes leigos (art. $24, \S 2^{\circ}$ ). A investidura arbitral, portanto, tem conotação eventual e não permanente. Seja pela própria natureza essencial das funções que exercem, seja pelas peculiaridades da disciplina de sua permanência no juizado e participação nos casos, os auxiliares parajurisdicionais não se enquadram comodamente na categoria dos permanentes nem na dos eventuais. Constituem categoria própria, paralela a essas". DINAMARCO, Cândido Rangel. Instituições de Direito Processual Civil. São Paulo: Malheiros Editores. 6. ed. 4 v. V. 1, p. 689-690.

${ }^{80}$ Cf. art. 327, caput, do Código Penal. SOUZA, Marcia Cristina Xavier. Juizados Especiais Fazendários. Rio de Janeiro: Forense, 2010, p. 79.

${ }^{81}$ Cf. art. 13, parágrafo único, da Lei 2.556/1996 do Estado do Rio de Janeiro, no que diz respeito aos Juizados Especiais Cíveis; e art. 34, parágrafo único, da Lei 5.781/2010 do Estado do Rio de Janeiro, no que concerne aos Juizados Especiais da Fazenda Pública.

${ }^{82}$ Cf. art. $144, \mathrm{CPC} / 2015$.

${ }^{83} \mathrm{Cf}$. art. $145, \mathrm{CPC} / 2015$.

${ }^{84}$ Nesse sentido, o art. $5^{\circ}$ da Resolução n. ${ }^{\circ} 174 / 2013$ do Conselho Nacional de Justiça dispõe que: "Os juízes leigos estão sujeitos aos mesmos motivos de impedimento e suspeição dos juízes togados". BRASIL. Conselho Nacional de Justiça. Resolução $\mathrm{n}^{\circ}$ 174, de 12 de abril de 2013. Brasília, DF. Disponível em: $<$ http://www.cnj.jus.br/atos-administrativos/atos-da-presidencia/resolucoespresidencia/24281-resolucao-n174-de-12-de-abril-de-2013>. Acesso em: 20 out. 2014.

85 "Art. 138. Aplicam-se também os motivos de impedimento e de suspeição: [...] II - ao serventuário de justiça; [...]”. BRASIL. Código de Processo Civil (Lei 5.869, de 11 de janeiro de 1973). Disponível em: $<$ http://www.planalto.gov.br/ccivil_03/leis/15869.htm>. Acesso em: 15 out. 2014.

${ }^{86}$ SODRÉ, Eduardo. Juizados Especiais Cíveis: Processo de Conhecimento. 1. ed. Rio de Janeiro: Lumen Juris, 2005, p. 26.
} 
Revista Eletrônica de Direito Processual - REDP. Volume 16. Julho a dezembro de 2015

Periódico Semestral da Pós-Graduação Stricto Sensu em Direito Processual da UERJ

Patrono: José Carlos Barbosa Moreira. ISSN 1982-7636. pp. 449-477 http://www.e-publicacoes.uerj.br/index.php/redp/index

Assim como todos os demais sujeitos processuais, o juiz leigo deve observar o princípio da cooperação. Assim, deve cumprir os deveres de esclarecimento, de prevenção, de consulta, de auxílio; e de correção e urbanidade; todos decorrentes do princípio da cooperação ${ }^{87}$.

Em atenção ao dever de prevenção, o juiz leigo deve alertar as partes sobre a conveniência do patrocínio por advogado, quando a causa o recomendar ${ }^{88}$. Sendo facultativa a assistência, se uma das partes comparecer assistida por advogado, ou se o réu for pessoa jurídica ou firma individual, o juiz leigo deve informar à outra parte de que esta tem direito à assistência judiciária prestada por órgão instituído junto ao Juizado Especial, na forma da lei local ${ }^{89}$. Da mesma forma, deve advertir as partes desassistidas por advogados da possibilidade de patrocínio pela Defensoria Pública para a interposição de recurso ${ }^{90}$, desde que não estejam em condições de pagar as custas do processo e os honorários de advogado, sem prejuízo próprio ou de sua família, nos termos da Lei 1.050/1960.

Em razão do dever de esclarecimento, o juiz leigo deve: “informar às partes, no início das sessões de conciliação e das audiências de instrução e julgamento, sua condição de auxiliar da justiça subordinado ao juiz togado" 91; "inserir, em seu projeto de sentença, texto informando que o referido projeto estará sujeito à homologação pelo juiz togado" ${ }^{92}$;

\footnotetext{
${ }^{87}$ Sobre o princípio da cooperação no processo civil, cf. SOUZA. Miguel Teixeira de. Aspectos do novo processo civil português. Revista Forense, v. 93, n. 338, p. 149-158, abr./ jun. 1997. Cf., ainda, MITIDIERO, Daniel. Colaboração no processo civil: pressupostos sociais, lógicos e éticos. 2. ed. São Paulo: Revista dos Tribunais, 2011. Da mesma forma, QUEIROZ, Pedro Gomes de. O princípio da cooperação e a exibição de documento ou coisa no Processo Civil. 2014. 219 f. Dissertação (Mestrado em Direito Processual) Faculdade de Direito, Universidade do Estado do Rio de Janeiro, Rio de Janeiro, 2014.

${ }^{88}$ Nesse sentido, o art. $9^{\circ}, \S 2^{\circ}$, da Lei 9.099/1995 determina que: "O Juiz alertará as partes da conveniência do patrocínio por advogado, quando a causa o recomendar". BRASIL. Lei n. ${ }^{\circ}$ 9.099, de 26 de setembro de 1995. Disponível em: <http://www.planalto.gov.br/ccivil_03/leis/19099.htm>. Acesso em: 15 out. 2014.

${ }^{89}$ Nesse sentido, o art. $9^{\circ}, \S 1^{\circ}$, da Lei 9.099/1995 estabelece que: "Sendo facultativa a assistência, se uma das partes comparecer assistida por advogado, ou se o réu for pessoa jurídica ou firma individual, terá a outra parte, se quiser, assistência judiciária prestada por órgão instituído junto ao Juizado Especial, na forma da lei local". BRASIL. Lei n. ${ }^{\circ}$ 9.099, de 26 de setembro de 1995. Disponível em: $<$ http://www.planalto.gov.br/ccivil_03/leis/19099.htm>. Acesso em: 15 out. 2014.

${ }^{90}$ Há recomendação nesse sentido em RIO DE JANEIRO (Estado). Tribunal de Justiça. Aviso n. ${ }^{\circ} 23$ de 2008 do Presidente do Tribunal de Justiça do Estado do Rio de Janeiro. Disponível em: $<$ http://www.tjrj.jus.br/institucional/juiz_especiais/documentos/pdf/aviso23-2008.pdf $>$. Acesso em: 18 out. 2014.

${ }^{21}$ Cf. art. $3^{\circ}$, V, do Código de Ética de Juiz Leigo, Anexo II da Resolução n. ${ }^{\circ}$ 174/2013 do Conselho Nacional de Justiça.

${ }^{92}$ Nesse sentido, Nesse sentido, cf. RIO DE JANEIRO (Estado). Tribunal de Justiça. Enunciado Administrativo n. ${ }^{\circ} 1.10$ do Aviso n. ${ }^{\circ} 23$ de 2008 do Presidente do Tribunal de Justiça do Estado do Rio de Janeiro. Disponível em: <http://www.tjrj.jus.br/institucional/juiz_especiais/documentos/pdf/aviso23-2008.pdf $>$. Acesso em: 18 out. 2014.
} 
Revista Eletrônica de Direito Processual - REDP. Volume 16. Julho a dezembro de 2015

Periódico Semestral da Pós-Graduação Stricto Sensu em Direito Processual da UERJ

Patrono: José Carlos Barbosa Moreira. ISSN 1982-7636. pp. 449-477 http://www.e-publicacoes.uerj.br/index.php/redp/index

"fundamentar os projetos de sentença, em linguagem que respeite as exigências técnicas e facilite a compreensão a todos, ainda que não especialistas em Direito" 93; "informar às partes, de forma clara e imparcial, os riscos e consequências de uma demanda judicial" "94; bem como "informar à vítima com clareza sobre a possibilidade de sua intervenção no processo penal e de obter a reparação ao dano sofrido" 95 .

São também deveres éticos do juiz leigo: "buscar a resolução do conflito com qualidade, acessibilidade, transparência e respeito à dignidade das pessoas, priorizando a tentativa de resolução amigável do litígio" 96; "zelar pela dignidade da Justiça" 97; "velar por sua honra e reputação pessoal e agir com lealdade e boa-fé" 98; "abster-se da captação de clientela no exercício da função de juiz leigo" 99; "respeitar o horário marcado para o início das sessões de conciliação e das audiências de instrução" 100; "dispensar tratamento igualitário às partes, independente de sua condição social, cultural, material ou qualquer outra situação de vulnerabilidade e, observar o equilíbrio de poder" 101; "abster-se de fazer pré-julgamento da causa" 102, "preservar o segredo de justiça quando for reconhecido no processo" 103; "guardar absoluta reserva e segredo profissional em relação aos fatos ou dados conhecidos no exercício de sua função ou por ocasião desta" 104.

\section{A remuneração do juiz leigo}

O art. $8^{\circ}$, da Resolução n. ${ }^{\circ} 174$ do Conselho Nacional de Justiça estabelece que juiz leigo deve ser remunerado por projeto de sentença ou acordo entre as partes homologado por sentença do juiz togado. Assim, não recebe qualquer remuneração pelo trabalho realizado em um processo, caso o resultado final deste - projeto de sentença ou acordo celebrado pelas partes - não venha a ser homologado. Concordamos com este sistema de remuneração, pois

\footnotetext{
${ }^{93}$ Cf. art. $4^{\circ}$ do Código de Ética de Juízes Leigos, Anexo II da Resolução n. ${ }^{\circ}$ 174/2013 do Conselho Nacional de Justiça.

${ }^{94}$ Cf. art. $3^{\text {o }}$, VI, Ibid.

${ }^{95} \mathrm{Cf}$. art. $3^{\mathrm{o}}$, VII, Ibid.

${ }^{96} \mathrm{Cf}$. art. $2^{\text {o }}$, Ibid.

${ }^{97} \mathrm{Cf}$. art. $3^{\text {o }}$, I, Ibid.

${ }^{98} \mathrm{Cf}$. art. $3^{\circ}$, II, Ibid.

${ }^{99} \mathrm{Cf}$. art. $3^{\mathrm{o}}$, III, Ibid.

${ }^{100} \mathrm{Cf}$. art. $3^{\mathrm{o}}$, IV, Ibid.

${ }^{101}$ Cf. art. $3^{\circ}$, VIII, Ibid.

${ }^{102} \mathrm{Cf}$. art. $3^{\circ}$, IX, Ibid.

${ }^{103} \mathrm{Cf}$. art. $3^{\mathrm{o}}$, X, Ibid.

${ }^{104}$ Cf. art. $3^{\circ}$, XI, Ibid.
} 
Revista Eletrônica de Direito Processual - REDP. Volume 16. Julho a dezembro de 2015

Periódico Semestral da Pós-Graduação Stricto Sensu em Direito Processual da UERJ

Patrono: José Carlos Barbosa Moreira. ISSN 1982-7636. pp. 449-477 http://www.e-publicacoes.uerj.br/index.php/redp/index

ele estimula o juiz leigo a conduzir seu trabalho com esmero e a seguir as orientações e o entendimento do juiz togado, o que contribui para a observância das garantias constitucionais do devido processo legal ${ }^{105}$, do contraditório ${ }^{106}$, da duração razoável do processo $^{107}$ e do acesso ao direito ${ }^{108}$. O referido dispositivo limita a remuneração do juiz leigo a do "maior cargo cartorário de terceiro grau de escolaridade do primeiro grau de jurisdição do Tribunal de Justiça, vedada qualquer outra equiparação". Estabelece, ainda que os projetos de sentença que extinguem o processo por ausência do autor à audiência de instrução e julgamento ou por desistência da ação não são remunerados, ainda que venham a ser homologados por sentença do juiz togado. Da mesma forma, determina que não devem ser remuneradas as decisões do juiz leigo quanto a embargos de declaração ${ }^{109}$. Entendemos, contudo, que o juiz leigo não pode decidir embargos de declaração, já que a lei não prevê o cabimento deste recurso do projeto, mas, tão somente, da sentença, que é ato exclusivo do juiz togado. Assim, somente o juiz togado pode decidir eventuais embargos de declaração interpostos pela parte.

\section{Considerações finais}

O constituinte teve por fim ampliar a participação popular na administração da justiça ao prever a figura do juiz leigo no art. 98 , I, da Constituição Federal ${ }^{110}$. Tal intento, contudo, acabou frustrado, pois os juízes leigos nunca foram diretamente eleitos pelo povo em

\footnotetext{
${ }^{105}$ Cf. art. $5^{\circ}$, LIV, CF/1988.

${ }^{106} \mathrm{Cf}$. art. $5^{\circ}, \mathrm{LV}, \mathrm{CF} / 1988$.

${ }^{107}$ Cf. art. $5^{\circ}$, LVIII, CF/1988.

${ }^{108}$ Cf. art. $5^{\circ}, \mathrm{XXXV}, \mathrm{CF} / 1988$.

${ }^{109}$ BRASIL. Conselho Nacional de Justiça. Resolução no 174, de 12 de abril de 2013. Brasília, DF. Disponível em: <http://www.cnj.jus.br/atos-administrativos/atos-da-presidencia/resolucoespresidencia/24281-resolucaon-174-de-12-de-abril-de-2013>. Acesso em: 20 out. 2014.

${ }^{110}$ Consta da ata da $3^{\text {a }}$ reunião ordinária, da Subcomissão do Poder Judiciário e do Ministério Público da Comissão da Organização e Sistema de Governo da Assembleia Nacional Constituinte de 1988, realizada no dia 14 abr. 1987, que o constituinte Jairo Carneiro, que então presidia a referida subcomissão, disse: “É preciso que haja tribunais populares - os juizados aqui mencionados - para que desafoguemos a Justiça de uma série de demandas que não devem acudir ao Judiciário formalmente como poder, eis que poderiam ser resolvidas com a participação da comunidade, dos cidadãos, tornando a sociedade mais fraterna e solidária e, inclusive, reduzindo os conflitos entre cidadãos e segmentos da sociedade. Podemos ter uma democracia mais participativa, mais solidária e mais fraterna, utilizando esses mecanismos que existem em outros países com estágio de desenvolvimento igual ao nosso e também em países mais avançados”. BRASIL. Assembleia Nacional Constituinte [de 1988] (ata das comissões). Comissão da Organização e Sistema de Governo. Subcomissão do Poder Judiciário e do Ministério Público. Disponível em: $<$ http://www.senado.gov.br/publicacoes/anais/asp/CT_Abertura.asp >. Acesso em: 29 out. 2014.
} 
Revista Eletrônica de Direito Processual - REDP. Volume 16. Julho a dezembro de 2015

Periódico Semestral da Pós-Graduação Stricto Sensu em Direito Processual da UERJ

Patrono: José Carlos Barbosa Moreira. ISSN 1982-7636. pp. 449-477 http://www.e-publicacoes.uerj.br/index.php/redp/index

qualquer dos Estados da Federação. O Conselho Nacional de Justiça veio, por fim, estabelecer que os juízes leigos devem ser selecionados "por meio de processo seletivo público de provas e títulos, ainda que simplificado, conduzido por critérios objetivos" $" 111$, inviabilizando o propósito originário do constituinte.

O Judiciário brasileiro atualmente concebe o juiz leigo, dentro da ideologia da eficiência, como uma forma de economizar dinheiro, pois sua hora de trabalho custa muito menos do que a do juiz togado ${ }^{112}$, e de poupar tempo, pois reduzindo o papel do juiz togado, nos Juizados Especiais Cíveis e nos Juizados Especiais da Fazenda Pública, ao de simples revisor e homologador dos projetos de sentença elaborados pelo juiz leigo, permite o proferimento de um número muito maior de sentenças num mesmo período de tempo, o que confere maior celeridade aos processos.

A lei deveria estabelecer a obrigatoriedade da ampla divulgação, no quadro de avisos do cartório e pela internet, da lista de todos os juízes leigos que atuam perante cada serventia.

\section{REFERÊNCIAS BIBLIOGRÁFICAS}

BRASIL. Assembleia Nacional Constituinte [de 1988] (ata das comissões). Comissão da Organização e Sistema de Governo. Subcomissão do Poder Judiciário e do Ministério Público.

\footnotetext{
${ }^{111}$ Cf. art. $2^{\circ}$ da Resolução n. ${ }^{\circ}$ 174/2013, do Conselho Nacional de Justiça.

112 O Edital do I Processo Seletivo para a Função de Juiz Leigo no Âmbito dos Juizados Especiais Cíveis do Poder Judiciário do Estado do Rio De Janeiro, de 30 jan. 2014, estabelece que: "1.4 Pelo exercício da função de Juiz Leigo é fixada retribuição mediante bolsa por ato homologado, projeto de sentença ou acordo celebrado entre as partes, não sendo computados para efeito de remuneração, as homologações de sentença de extinção do processo no caso de ausência do autor, desistência e embargos de declaração, sem prejuízo de outras situações que venham a ser regulamentadas pelo Tribunal de Justiça. Atualmente a retribuição paga é de R\$ 22,00 (vinte e dois reais), por ato homologado, sendo que, nos termos do artigo $6^{\circ}$ da Resolução $\mathrm{TJ} / \mathrm{OE} / \mathrm{RJ} \mathrm{n}^{\circ}$ 35/2013, cada Juiz Leigo deverá realizar, no mínimo, 80 audiências, por mês, bem como, elaborar, no mínimo, 80 projetos de sentença, por mês, podendo tal meta ser alterada por deliberação da Comissão Judiciária de Articulação dos Juizados Especiais - COJES. 1.5 A remuneração, em qualquer caso, não poderá ultrapassar o maior cargo cartorário de terceiro grau de escolaridade do primeiro grau de jurisdição do Tribunal de Justiça". RIO DE JANEIRO (Estado). Edital do I Processo Seletivo para a Função de Juiz Leigo no Âmbito dos Juizados Especiais Cíveis do Poder Judiciário do Estado do Rio de Janeiro. Disponível em: $<$ http://www.tjrj.jus.br/documents/10136/1627603/minuta-edital-juiz-leigo.pdf?=v3>. Acesso em: 29 out. 2014. Por outro lado, o edital do XLVI Concurso para Ingresso na Magistratura de Carreira do Estado do Rio de Janeiro, de 10 mar. 2014, estabelece que: "3.3. A remuneração do cargo de Juiz Substituto é de R\$22.797,33 (vinte e dois mil, setecentos e noventa e sete reais e trinta e três centavos)". RIO DE JANEIRO (Estado). Edital do XLVI Concurso para Ingresso na Magistratura de Carreira do Estado do Rio de Janeiro. Disponível em: $<$ http://www.tjrj.jus.br/documents/10136/1644050/edital-10-03-14.pdf $>$. Acesso em: 29 out. 2014.
} 
Revista Eletrônica de Direito Processual - REDP. Volume 16. Julho a dezembro de 2015

Periódico Semestral da Pós-Graduação Stricto Sensu em Direito Processual da UERJ

Patrono: José Carlos Barbosa Moreira. ISSN 1982-7636. pp. 449-477 http://www.e-publicacoes.uerj.br/index.php/redp/index

$<$ http://www.senado.gov.br/publicacoes/anais/asp/CT_Abertura.asp >. Acesso em: 29 out. 2014.

- Código de Processo Civil (Lei 13.105/2015). Disponível em: $<$ http://www.planalto.gov.br/ccivil_03/_Ato2015-2018/2015/Lei/L13105.htm>. Acesso em: 09 jun. 2015.

- Constituição da República Federativa do Brasil de 1988. Disponível em: $<$ http://www.planalto.gov.br/ccivil_03/Constituicao/Constituicao.htm>. Acesso em: 26 out. 2014.

. CONSELHO NACIONAL DE JUSTIÇA. Resolução nº 174, de 12 de abril de 2013.

Brasília, DF. Disponível em: <http://www.cnj.jus.br/atos-administrativos/atos-dapresidencia/resolucoespresidencia/24281-resolucao-n-174-de-12-de-abril-de-2013>.

Acesso em: 20 out. 2014.

Enunciados do Fórum Nacional de Juizados Especiais (FONAJE). Disponível em: $<$ http://www.fonaje.org.br/site/enunciados/>. Acesso em: 18 out. 2014.

. Lei 7.244, de 7 de novembro de 1984. Disponível em: $<$ http://www.planalto.gov.br/ccivil_03/leis/1980-1988/L7244.htm>. Acesso em: 13 out. 2014.

Lei 9.099, de 26 de setembro de 1995. Disponível em: $<$ http://www.planalto.gov.br/ccivil_03/leis/19099.htm>. Acesso em: 17 out. 2014.

- Lei n. ${ }^{\circ}$ 9.307, de 23 de setembro de 1996. Disponível em: $<$ http://www.planalto.gov.br/ccivil_03/Leis/L9307.htm>. Acesso em: 19 out. 2014.

. Lei 12.153, de 22 de dezembro de 2009. Disponível em: $<$ http://www.planalto.gov.br/ccivil_03/_Ato2007-2010/2009/Lei/L12153.htm>. Acesso em: 01 nov. 2011.

Lei de Introdução às normas do Direito Brasileiro (Decreto-Lei no 4.657 , de 4 de setembro de 1942). Disponível em: <http://www.planalto.gov.br/ccivil_03/decretolei/Del4657compilado.htm>. Acesso em: 15 out. 2014.

CÂMARA, Alexandre. Juizados Especiais Cíveis Estaduais e Federais: Uma Abordagem Crítica. 1. ed. Rio de Janeiro: Lumen Juris, 2007.

CARNEIRO, Paulo Cezar Pinheiro. Acesso à Justiça: juizados especiais cíveis e ação civil pública: uma nova sistematização da Teoria Geral do Processo. 2. ed. Rio de Janeiro: Forense, 2003. 
Revista Eletrônica de Direito Processual - REDP. Volume 16. Julho a dezembro de 2015

Periódico Semestral da Pós-Graduação Stricto Sensu em Direito Processual da UERJ

Patrono: José Carlos Barbosa Moreira. ISSN 1982-7636. pp. 449-477 http://www.e-publicacoes.uerj.br/index.php/redp/index

COSTALUNGA, Danilo Alejandro Mognoni. Sobre o exercício da advocacia por juízes leigos dos juizados especiais: para uma superação do conflito aparente de normas entre a Lei n. ${ }^{\circ}$ 8.906/94 e a Lei n. ${ }^{\circ}$ 9.099/95. Jus Navigandi, Teresina, ano 4, n. 31, 1 maio 1999. Disponível em: <http://jus.com.br/artigos/825>. Acesso em: 19 out. 2014.

DINAMARCO, Cândido Rangel. Instituições de Direito Processual Civil. São Paulo: Malheiros Editores. 6. ed. 4 v. V. 1.

GRECO, Leonardo. Instituições de processo civil. 3. ed. Rio de janeiro: Forense, 2011. 2 v. V.I: Introdução ao Direito Processual Civil.

LIMA, Roberto Kant de. A polícia da cidade do Rio de Janeiro: seus dilemas e paradoxos. 1. ed. Rio de Janeiro: Polícia Militar do Estado do Rio de Janeiro, 1994.

MITIDIERO, Daniel. Colaboração no processo civil: pressupostos sociais, lógicos e éticos. 2. ed. São Paulo: Revista dos Tribunais, 2011.

PINHO, Humberto Dalla Bernardina de. Direito Processual Civil Contemporâneo. 4 ed. São Paulo: Saraiva, 2012. 2v. V.1: Teoria Geral do Processo.

QUEIROZ, Pedro Gomes de. O princípio da cooperação e a exibição de documento ou coisa no Processo Civil. 2014. 219 f. Dissertação (Mestrado em Direito Processual) Faculdade de Direito, Universidade do Estado do Rio de Janeiro, Rio de Janeiro, 2014.

REALE, Miguel. Lições Preliminares de Direito. 27 ed. São Paulo: Saraiva, 2002.

RIO DE JANEIRO (Estado). Edital do I Processo Seletivo para a Função de Juiz Leigo no Âmbito dos Juizados Especiais Cíveis do Poder Judiciário do Estado do Rio de Janeiro. Disponível em: <http://www.tjrj.jus.br/documents/10136/1627603/minuta-edital-juizleigo.pdf?=v3>. Acesso em: 29 out. 2014.

. Edital do XLVI Concurso para Ingresso na Magistratura de Carreira do Estado do Rio de Janeiro. Disponível em: <http://www.tjrj.jus.br/documents/10136/1644050/edital10-03-14.pdf>. Acesso em: 29 out. 2014.

Lei $\mathrm{n}^{\mathrm{o}}$ 2.556, de 21 de maio de 1996. Disponível em: $<$ http://alerjln1.alerj.rj.gov.br/CONTLEI.NSF/e9589b9aabd9cac8032564fe0065abb4/c367 3b92b1caf6b6032564f8007cc6fc>. Acesso em: 15 out. 2014.

. Lei $n^{0}$ 5.781, de 01 de julho de 2010. [S.1.: s.n.], [2014] (data certa não indicada na publicação). Disponível em: $<$ http://alerjln1.alerj.rj.gov.br/CONTLEI.NSF/e9589b9aabd9cac8032564fe0065abb4/2896 71a6e642c5158325775f0057e2e0?OpenDocument>. Acesso em: 20 out. 2014. 
Revista Eletrônica de Direito Processual - REDP. Volume 16. Julho a dezembro de 2015

Periódico Semestral da Pós-Graduação Stricto Sensu em Direito Processual da UERJ

Patrono: José Carlos Barbosa Moreira. ISSN 1982-7636. pp. 449-477 http://www.e-publicacoes.uerj.br/index.php/redp/index

. Tribunal de Justiça. Aviso n. ${ }^{\circ} 23$ de 2008 do Presidente do Tribunal de Justiça do

Estado do Rio de Janeiro. Disponível em:

$<$ http://www.tjrj.jus.br/institucional/juiz_especiais/documentos/pdf/aviso23-2008.pdf $>$.

Acesso em: 18 out. 2014.

ROCHA, Felippe Borring. Juizados Especiais Cíveis: Aspectos Polêmicos da Lei n. ${ }^{\circ} 9.099$ de 26/9/1995. 4. ed. Rio de Janeiro: Lumen Juris, 2005.

SLAIB FILHO, Nagib. O Juiz leigo e o projeto de decisão referido no art. 40 da Lei $\mathbf{n}^{\mathbf{0}}$

9.099/95, p. 1. Disponível em: <http://www.nagib.net/index.php/publicacoes/artigos/civilprocesso-civil-consumidor/589-div2>. Acesso em: 06 nov. 2014.

SODRÉ, Eduardo. Juizados Especiais Cíveis: Processo de Conhecimento. 1. ed. Rio de Janeiro: Lumen Juris, 2005.

SOUZA, Marcia Cristina Xavier. Juizados Especiais Fazendários. Rio de Janeiro: Forense, 2010 .

SOUZA. Miguel Teixeira de. Aspectos do novo processo civil português. Revista Forense, Rio de Janeiro, v. 93, n. 338, p. 149-158, abr./ jun. 1997. 